\title{
DIREITO DA REGULARIZAÇÃO FUNDIÁRIA URBANA E AUTONOMIA MUNICIPAL: A CONVERSÃO DA MEDIDA PROVISÓRIA N. 759/2016 NA LEI FEDERAL N. 13.465/2017 E AS TITULAÇÕES DA PREFEITURA DA CIDADE DO RIO DE JANEIRO NO PRIMEIRO QUADRIMESTRE DE 2017
}

\author{
RIGHT OF URBAN LAND REGULARIZATION AND MUNICIPAL AUTONOMY: THE CONVERSION OF \\ PROVISIONAL MEASURE NO. 759/2016 IN FEDERAL LAW N. 13.465 / 2017 AND THE TITLES OF THE CITY \\ HALL OF RIO DE JANEIRO IN THE FIRST FOUR MONTHS OF 2017
}

\author{
Arícia Fernandes Correia ${ }^{1}$ \\ ${ }^{1}$ Universidade do Estado do Rio de Janeiro (UERJ), Rio de Janeiro, RJ, Brasil
}

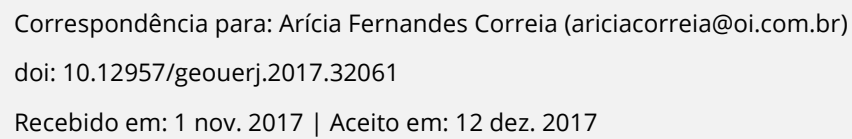

\section{RESUMO}

A Prefeitura da Cidade do Rio de Janeiro já desenvolve há mais de uma década um trabalho de tentativa de integração das favelas à malha formal da cidade, através de processos de regularização urbanística e fundiária, que culminam com a titulação de moradores de domicílios localizados em assentamentos precários consolidados, num trabalho longo e silencioso que se desenvolve depois de festejadas obras de urbanização como as dos programas Favela-Bairro e Morar-Carioca. O assunto ganhou destaque nacional recentemente, porém, com as intensas discussões acerca da edição da Medida Provisória n. 759, de 22 de dezembro de 2016 , que, entre as modificações de diversas matérias, tratou também, do tema da regularização fundiária urbana, culminando com sua conversão na Lei Federal n. 13.465, de 11 de julho de 2017. O presente artigo tem por objetivo discutir os avanços e retrocessos do novo marco regulatório nacional acerca da matéria, cotejando suas diferenças em relação à legislação anterior, que expressamente revogou, bem como perquirir acerca da natureza jurídica e mesmo da valia dos institutos novos que trouxe ao ordenamento jurídico - como a legitimação fundiária e o direito de laje -, tentando demonstrar que grande parte das críticas que se lhes opõem podem ser neutralizadas através da observância à Constituição, seja a ela mesma intrinsicamente, como um verdadeiro marco fundamental no prestígio à reforma urbana e sob uma perspectiva neoconstitucionalista, seja pela consagração que conferiu à autonomia municipal, uma vez que compete ao Município não só disciplinar matérias de interesse local, mas, também, legislar sobre o uso e a ocupação do solo, e, principalmente, ordenar o pleno desenvolvimento da cidade e da propriedade urbana, de forma que bem satisfaçam suas funções sociais. Neste sentido, a legislação local de que já dispõem as Comunas, unida a uma interpretação da Lei Federal n. 13.465/2017 conforme a Constituição, podem oferecer um contributo à mantença de uma visão progressista e holística de regularização fundiária plena e não de retrocesso a um conceito estritamente dominial, como pretendem alguns intérpretes da lei. Por fim, tendo como amostra as titulações do Município do Rio de Janeiro no primeiro quadriênio do ano de 2017, verificar-se-á o perfil socioeconômico de seus beneficiários: daqueles que carecem da segurança da posse ou de domínio de suas longevas ocupações e que se encontram em situação de vulnerabilidade não só socioeconômica, mas, também, jurídica e de que forma este pode ser um primeiro passo rumo a uma transformação neste quadro de desigualdade histórica em relação às estruturas fundiárias formais da legalidade brasileira, de que foram historicamente alijados, de modo a se (tentar) construir uma cidade mais equânime.

Palavras-chave Direito da Cidade. Regularização Urbanística e Fundiária. Legitimação Fundiária. 


\begin{abstract}
For more than a decade, the City of Rio de Janeiro has developed a work of attempting to integrate the favelas into the formal network of the city, through processes of urbanization and land tenure, which culminate in the titling of residents of located households in consolidated precarious settlements, in a long and silent work that takes place after celebrated works of urbanization like the programs of Favela-Bairro and Morar-Carioca. The subject has gained national proeminence recently, however, with the intense discussions about the edition of Provisional Measure n. 759, dated December 22, 2016, which, among the modifications of various subjects, also dealt with the theme of urban land regularization, culminating in its conversion into Federal Law no. 13,465, dated July 11, 2017. The purpose of this article is to discuss the advances and setbacks of the new national regulatory framework, comparing its differences with previous legislation, which it has expressly revoked, as well as to investigate the legal nature and even the value of the new institutes that legal order - such as land legitimization and slab rights - trying to demonstrate that much of the criticism that is opposed to them can be neutralized through observance of the Constitution, itself intrinsically, as a true fundamental landmark in the prestige of urban reform and from a neoconstitutionalist perspective, or by the effectiviness that conferred to the municipal autonomy, since it is the Municipality's duty not only to discipline matters of local interest, but also to legislate on the use and occupation of the land, and, especially, to order full development and urban property, so that its social functions work. In this sense, the local legislation already available to the Communes, together with an interpretation of Federal Law no. 13.465/2017 according to the Constitution, can offer a contribution to the maintenance of a progressive and holistic vision of full land regularization and not regression to a strictly concept of property, as some interpreters of the law wish. Lastly, taking as a sample the Rio de Janeiro Municipality's qualifications in the first four-year period of 2017, the socioeconomic profile of its beneficiaries will be verified: those who lack security of tenure or control of their long-term occupations and who are in a situation of vulnerability not only socioeconomic but also legal and in what form this can be a first step towards a transformation within this framework of historical inequality in relation to the formal land structures of Brazilian legality, so as to try to build a more equitable city.
\end{abstract}

Keywords: City Law. Urbanization and Land Tenure Regularization. Land Legitimation.

\title{
APRESENTAÇÃO
}

O histórico fundiário brasileiro sempre foi excludente: tirante os índios, que davam à terra mais que uma função social, um significado sagrado, a colonização portuguesa, de cunho extrativista, sempre tratou a terra como mercadoria: primeiro, como o que dela se podia extrair; depois, como o que ela mesma poderia ser - um "produto" de alto valor econômico, mensurável, diria Lefebvre (2001), pelo valor de troca e não pelo valor de uso.

Com efeito, no início da efetiva colonização, a partir de 1530, vigoraram, como sistema de ocupação, as capitanias hereditárias, às quais se seguiram as sesmarias, herdadas da legislação portuguesa, que vigiam além-mar e também aqui, em terras brasileiras, como verdadeiras subdivisões das capitanias.

Os "donatários" 1 ", enquanto administradores de parte das terras pertencentes à Coroa, poderiam conceder terras, condicionalmente, a quem as cultivasse, gerando ocupação e cultivo, mas, ao contrário

\footnotetext{
${ }^{1}$ Segundo Cirne Lima, o sistema das sesmarias se assemelha ao da enfiteuse, de modo que a Coroa não deixa de ter a propriedade do bem, por mais que o donatário tenha amplos poderes sobre a terra, inclusive o de dela dispor, até para
} 
de Portugal, onde as sesmarias serviram à construção e consolidação do povoamento do reino ibérico, em terras tupiniquins, contribuíram para com a formação de grandes latifúndios em mãos de uma elite escravagista: um Brasil de "coronelismo, enxada e voto" (LEAL, 1976) de cabresto, entre outras mazelas próprias ao nosso histórico fundiário, político e social.

"Quando o sistema de sesmarias foi extinto, pela Resolução n. 76 do príncipe regente de 17 de julho de 1822, no limiar da decretação da independência do Brasil, por força da reclamação de um lavrador, Manoel José dos Reis, que argumentou, junto a Dom Pedro I, que uma sesmaria fora outorgada sobre uma terra por ele ocupada há mais de vinte anos" (MELO, 2008, pp. 18 e 19), houve a possibilidade de a ocupação, a posse, ser tratada como instituto autônomo, mas dela só acabaram por se beneficiar os homens livres. E durou pouco. Por coincidência, no mesmo ano em que se extinguia o tráfico negreiro com a Lei Eusébio de Queiroz (Lei n. 581, de 1850)² , a Lei de Terras, Lei n. 601, de 1850, transformava a terra numa mercadoria que só os já proprietários ou ex-sesmeiros, cujas sesmarias fossem pela lei convalidadas - jamais os futuros escravos libertos (a extinção da escravatura só viria quase quatro décadas depois ...) - poderiam adquirir ${ }^{3}$.

Segundo Miguel Baldez (1991, p. 5):

\footnotetext{
A classe trabalhadora, principalmente a grande maioria dela, formada por trabalhadores de baixos salários, subempregados, biscateiros e desempregados, não têm, no Brasil, acesso à terra. O fato, consequência histórica do processo de acumulação capitalista, vai encontrar suas origens mais remotas no modo de produção escravagista, nos modos de aquisição e formação da propriedade durante o período colonial e depois da Lei n. 601, de 1850, na adoção da venda e compra como modalidade principal de aquisição da propriedade e na consolidação dos latifúndios,
}

terceiros, na qualidade de sesmeiro. (LIMA, 1988) Segundo DINIZ, deve-se (...) lembrar que as sesmarias não eram de domínio total dos donatários ricos, mas apenas lhes tocavam as partes de terras especificadas nas Cartas de Doações. Os donatários se constituíram em administradores investidos de mandatos da Coroa para doar as terras. Receberam a capitania com a finalidade colonizadora. Eles não tinham poderes ilimitados, não foram legitimadores nem do público nem do privado $\mathrm{e}$ cabia-lhes apenas cumprir as ordens de Portugal. (...) A terra continuava a ser patrimônio do Estado português. Os donatários possuíam o direito de usufruir da propriedade mas não tinham o direito como donos. (...) Os capitães-donatários só detinham $20 \%$ da sua capitania e eram obrigados a distribuir os $80 \%$ restantes, a título de sesmaria, não conservando nenhum direito sobre estas." (DINIZ, 2017)

${ }^{2}$ A expressão popular, até hoje muito usada, "lei para inglês ver", teria surgido com a Lei Eusébio de Queirós, provavelmente criada pelo povo, fazendo referência à lei que teria sido criada para atender às exigências dos ingleses, porém com pouco efeito prático em seus primeiros anos de aplicação.

${ }^{3}$ Para um histórico completo acerca do tema, confira-se a dissertação de mestrado de Rafael Mota, da linha de pesquisa de Direito da Cidade do Programa de Pós-Graduação em Direito da Universidade do Estado do Rio de Janeiro, então orientando da autora. 
através da medição e da demarcação das sesmarias outorgadas e ocupações havidas enquanto vigorava o colonialato.

Era o início da divisão social fundiária brasileira entre proprietários e não proprietários.

Ainda não havia favelas no Rio de Janeiro. Mas, também por não menor coincidência, aquela que é considerada a primeira delas - o Morro da Providência; então, Morro da Favella -, teria se formado no início do século XX, pouco depois do fim tardio da escravidão, em 1888, para cuja ocupação teriam contribuído os escravos recém-libertos, os egressos da Guerra de Canudos e os expulsos dos cortiços, então proibidos pela reforma urbana conduzida por Pereira Passos e, neste caso, de um dos maiores deles, que ficava em suas imediações: o cortiço cabeça de porco. (MAGALÃES, 1995) "Cidade desde o início marcada pelo paradoxo, a derrubada dos cortiços resultou no crescimento da população pobre nos morros, charcos e demais áreas vazias em torno da capital.” (ZALVAR; ALVITO, 2006, p. 7)

A história das favelas do Rio de Janeiro se confunde, portanto, com o seu processo de urbanização e de apropriação do espaço urbano pela elite colonial-escravagista; depois pela aristocracia imperial; e finalmente pela nobreza republicana. Entre uma corrente e outra há muito de força de trabalho imigratória, de self made men and women e de uma vasta parcela da população de gerações posteriores que teve oportunidades de ensino e de trabalho de que sempre foram alijados os socialmente mais vulneráveis, mas entre elas não estariam incluídos, como se verificará através dos dados empíricos coligidos, os moradores de favelas ${ }^{4}$ : esses se incluem até hoje no grupo dos não proprietários. ${ }^{5}$

Para o escopo deste artigo, todavia, a grande questão é que as favelas, em primeiro lugar, se não nasceram, se consolidaram naquela que foi considerada uma das mais bem sucedidas reformas urbanas cariocas - a de Pereira Passos -, e, em segundo, por longas décadas, ficaram alijadas dos mapas da

\footnotetext{
${ }^{4}$ De acordo com o Censo 2010 do IBGE, o nome técnico apropriado são "aglomerados subnormais", nomenclatura que engloba os diversos tipos de assentamentos irregulares existentes no País, como favelas, invasões, grotas, baixadas, comunidades, vilas, ressacas, mocambos, palafitas, entre outros. (BRASIL, 2010)

${ }^{5}$ Conforme verificar-se-á através da análise dos dados primários coligidos para esta pesquisa, a maioria esmagadora dos beneficiários de títulos de regularização fundiária casados sequer presta informações, no momento da respectiva qualificação, sobre seus regimes de bens.
} 
cidades e, consequentemente, do planejamento urbanístico; ou, ao contrário, foram incluídas por exclusão: mediante políticas de remoção das décadas de $30^{6}, 40$ e 50, fazendo fracassar a promessa da integração da favela ao bairro, do morro ao asfalto, desse binário do eu e do teu e nunca um amálgama do nós, o que o planejamento urbano só tentaria reparar décadas mais tarde.?

Durante muito tempo elas sequer constavam dos mapas da Cidade do Rio de Janeiro. Mas, diferentemente do que se fez com o Cemitério dos Pretos Novos, soterrado para que a cidade esquecesse a maneira indigna com que enterrava seus escravos mortos à chegada do Porto, "à flor da terra” (PEREIRA, 2007), não foi possível remover as favelas do cenário urbano carioca. Elas se incorporaram à paisagem urbana, seja nua e crua, seja colorida e pulsante. Não foram planejadas; se auto-planejaram, se auto-construíram, se “auto-formalizaram” com sistemas registrais próprios, sempre à margem: da cidade, da legalidade, da Administração.

Mas nunca - ou raramente ${ }^{8}$ - tiveram um pedaço de terra para chamar de seu. Pelo menos, não do ponto de vista legal-cartorário.

Várias legislações nacionais trataram, direta ou indiretamente, do tema da regularização fundiária no Brasil, ainda que de forma tímida, como no caso exemplar da lei que criou a concessão de direito real de uso, fornecida no bojo de processos de regularização de assentamentos precários de interesse social por todo o país (principalmente através das unidades descentralizadas de gestão do patrimônio público federal), e da famosa Lei de Parcelamento de Uso do Solo Urbano: a Lei Federal n. 6.766/1979, mas, sem dúvida, foi a Reforma Urbana preconizada pela Constituição e a previsão nela mesma de institutos de regularização urbanística e fundiária, como a usucapião urbana pro morare e a base para a concessão de uso especial para fins de moradia, de princípios estruturantes, como o da função social da

\footnotetext{
${ }^{6}$ Segundo Lessa, a pobreza e o aparecimento das favelas é um problema que surge nos anos 1930 e já é enfrentado pelo Plano Agache, sendo que a política de remoção das favelas é estabelecida no período pós segunda Guerra Mundial, sendo Carlos Lacerda o grande porta voz da política de remoção das favelas na cidade, criando conjuntos habitacionais nos subúrbios que se tornarão áreas de fortes tensões sociais. (LESSA, 2001)

${ }^{7}$ Acusam-se os megaeventos das Olimpíadas e da Copa do Mundo de responsáveis por uma nova leva de remoções/reassentamentos na cidade. (RIBEIRO, 2016).

${ }^{8}$ A Secretaria Municipal de Habitação, responsável pela Política de Habitação da Cidade do Rio de Janeiro, só veio a ser criada em 1994, através da Lei Municipal nº 2.262.
} 
propriedade urbana e da Cidade e da justa distribuição dos bônus e ônus urbanísticos, que se elevou a matéria ao status fundamental, a partir do qual se pode e deve interpretar toda a legislação infraconstitucional.

Nesta esteira, o grande salto de sistematização da visão e do processo como um todo de regularização fundiária plena adotado pela doutrina e legislação nacional foi, inequivocamente, a Lei Federal n. 11.977/2009 ${ }^{9}$, intitulada como Programa Minha Casa, Minha Vida.

Para fins metodológicos, o presente artigo tem por objetivo discutir os avanços e retrocessos do novo marco regulatório nacional acerca da matéria, levando em consideração e edição da Medida Provisória n. 759/2016 e seu processo de conversão, através das discussões acerca do Projeto de Lei de Conversão n. 12/2017 para chegar à lei em si: a Lei Federal n. 13.465/2017 -, cotejando suas diferenças em relação à legislação anterior (Lei Federal n. 11.977/2009), cujo capítulo dedicado ao tema expressamente revogou, bem como perquirir acerca da natureza jurídica e mesmo da valia de um dos institutos novos que trouxe ao ordenamento jurídico, a legitimação fundiária, tentando demonstrar que grande parte das críticas que se lhes opõem podem ser neutralizadas através do prestígio à Constituição, seja a ela mesma intrinsicamente, como um verdadeiro marco fundamental da reforma urbana brasileira, seja pela consagração que conferiu à autonomia municipal, uma vez que compete ao Município não só disciplinar matérias de interesse local, mas, também, legislar sobre o uso e a ocupação do solo, e, principalmente, ordenar o pleno desenvolvimento da cidade e da propriedade urbana, de forma que bem satisfaçam suas funções sociais.

Neste sentido, a legislação local de que já dispõem as Comunas, unida a uma interpretação da Lei Federal n. 13.465/2017 conforme a Constituição, podem oferecer um contributo à mantença de uma visão progressista e holística de regularização fundiária plena e não de retrocesso a um conceito estritamente dominial, de que se acusa o novo marco regulatório.

\footnotetext{
${ }^{9}$ Obviamente que Municípios e também Estados detinham legislações dedicadas ao tema da regularização urbanística e fundiária, mas não com a força de norma geral própria às leis federais/nacionais. De toda forma, adiante se reconhecerá a vigência e eficácia dessa legislação municipal, fruto da competência local para tratar do planejamento urbano da cidade e, por consequência, do tema da regularização urbanística e fundiária das favelas.
} 
Por fim, utilizando-se de dados primários coligidos junto à Coordenadoria de Regularização Urbanística e Fundiária da Subsecretaria de Habitação da Prefeitura da Cidade do Rio de Janeiro ${ }^{10}$, tendo como amostra as titulações do Município do Rio de Janeiro no ano de 2017, verificar-se-á o perfil socioeconômico de seus beneficiários: daqueles que carecem da segurança da posse ou de domínio de suas longevas ocupações e que se encontram em situação de vulnerabilidade não só socioeconômica, mas, também, jurídica e de que forma este pode ser um primeiro passo rumo a uma transformação neste quadro de desigualdade histórica em relação às estruturas fundiárias formais da legalidade brasileira, de que foram historicamente alijados, de modo a se (tentar) construir uma cidade mais equânime, permitindo que tenham acesso mais que ao direito à moradia (seja pela posse ou pela propriedade), o direito à cidade.

\section{Regularização Urbanística e Fundiária (ou Regularização Fundiária Plena)}

\section{Conceitualmente: Regularização Fundiária stricto sensu e lato sensu}

Neste sentido, já se teve oportunidade de observar que a regularização fundiária plena de assentamentos precários no Brasil se apresenta sob diferentes facetas: a dominial-registral, que garante a segurança da posse ou o título de propriedade, através dos mais diversos instrumentos jurídicos; a urbanística, em razão da qual se garante uma legislação de uso e ocupação do solo própria, infraestrutura urbana, equipamentos coletivos, direito fundamental ao endereço, conexão com a cidade (mobilidade); e a socioambiental, de maneira que se garanta a mantença das pessoas tituladas preferencialmente em seus locais de pertencimento, de forma integrada ao ambiente em que

\footnotetext{
${ }^{10}$ Após a união das Secretarias de Urbanismo, Obras e Habitação numa única Pasta - a Secretaria Municipal de Urbanismo, Infraestrutura e Habitação, pelo Decreto Municipal n. 42.719, de $1^{\circ}$ de janeiro de 2017 -, criou-se, no âmbito da Subsecretaria de Habitação, a Coordenadoria de Regularização Urbanística e Fundiária, através do Decreto Municipal n. 42.850, de 25 de janeiro de 2017, que uniu as antigas atribuições da Gerência de Regularização Urbanística e Fundiária da então Pasta de Habitação com as da Coordenadoria de Interesse Social da antiga Secretaria de Urbanismo, na qual se encontravam os Postos de Orientação Urbanística e Fundiária (POUSOS), exceto a atribuição da fiscalização, compreendendo-se, finalmente, o direito à habitação no contexto do direito à urbe, à cidade: à moradia adequada que compreende o sentido de pertença à cidade, de cidadania.
} 
(sobre)vivem, devendo se caracterizar, finalmente, como sustentável ${ }^{11}$, não apenas do ponto de vista ambiental, mas, também, social.

Carlos Ari Sundfeld (2002) selou um diagnóstico preciso acerca da nova "ordem urbanística popular", no sentido de identificar que ela inverte a lógica pretérita da urbanização e regularização: no lugar de a cidade informal ter que se adaptar à legislação urbanística, é esta que passa a ter que se adaptar às novas conformações espaciais da cidade, mediante absorção, sempre que possível, dos parâmetros urbanísticos dos assentamentos informais à cidade formal, como quando na hipótese de áreas demarcadas como Zonas Especiais de Interesse Social, nas quais será viável adotar padrões mais flexíveis de uma urbanização possível - e não de uma idílica cidade cujo sonho estaria sempre condenado à frustração diante da inexorabilidade da vida tal qual ela é e da cidade, tal qual ela costuma ser cotidianamente (re)construída por aqueles que a habitam ${ }^{12}$.

Por isso, a regularização fundiária de assentamento precário é mais do que titulação de domínio ou segurança de posse urbana; é, também, a integração da moradia à cidade.

Com efeito, regularização fundiária plena é o processo através do qual, após a devida urbanização da área, mediante obras de infraestrutura urbana (saneamento, drenagem, arruamento), (i) se enquadra 0 imóvel em padrões urbanísticos que garantam a regularidade urbanística da área (planejamento urbano local, legislação própria de uso e ocupação do solo, nomeação de logradouros); (ii) se titula o proprietário da terra ou se garante a sua posse (pelos mais variados títulos); (iii) se articula a oferta de melhorias habitacionais e socioambientais (serviços públicos locais à população da comunidade, como saúde, educação, trabalho e renda) que garantam sua sustentabilidade; (iv) se promove o contínuo diálogo urbano (a efetiva participação cidadã), de forma a torná-la participativa, de modo a

${ }^{11}$ CORREIA, Arícia Fernandes. COSTA, Emerson Affonso e MOTA, Maurício. Função Socioambiental da Propriedade Privada e Regularização Fundiária Sustentável. Belo Horizonte: Editar, 2016.

${ }^{12}$ A partir daí, há todo um esforço no sentido de se manter a regularidade urbanística alcançada com a nova legislação, de modo a evitar o retorno à informalidade, à precariedade e à insuficiência dos equipamentos coletivos concebidos para aquela dada comunidade, fenômenos que nem sempre resistem a fatores como aumento da pobreza, explosão demográfica e ônus cartorários excessivos. É do que trata um artigo sobre a análise, dezoito anos depois, de um programa de regularização de propriedade na ilha do Caribe chamada St. Lucia. (BARNES; GRIFFITH, 2007, pp. 494-501) 
que a própria comunidade beneficiária se aproprie de seu conceito, valorize a regularidade e passe ela mesma a cuidar do espaço público não mais como terra de ninguém, mas de todos, e, enfim, (v) se integra a moradia à cidade, de forma que se tenha por segura a posse ou "titulado" o domínio de moradia adequada e digna, que é aquela que proporciona não apenas aquele direito à cidade "de puertas para adentro" (um teto, a inviolabilidade do domicílio, condições de habitabilidade minimamente dignas), mas também "de puertas para afuera" (ACOSTA, 2014, p. 70): a cidade, à qual, para ser efetivamente digna, a moradia deve ser integrada.

Na visão de Ligia Melo (2010, pp. 184 e 185),

\footnotetext{
...) o programa de regularização tem por objetivo promover, concomitantemente, a integração socioespacial das áreas ocupadas pela população de baixa renda e a segurança jurídica da posse de seus habitantes. Porém, não há possibilidade de ver esse processo curativo dar certo sem que haja a articulação de várias ações públicas dirigidas a seus ocupantes, o que inclui uma política social forte, incluida a de geração de renda. (...) um conjunto de medidas que induzam ao desenvolvimento socioeconômico, que interrompa o ciclo de exclusão social.
}

Neste sentido, pode-se resumir que há dois conceitos básicos de regularização fundiária: (i) o stricto sensu, meramente registral, como o que ocorreu no Peru, onde milhares de pessoas foram tituladas, mas os índices de qualidade de vida pouco oscilaram e (ii) o da regularização fundiária plena, que envolve todos os aspectos antes assinalados e que, por isso, é mais cara, porém, muito mais sólida, historicamente adotada no Brasil.(FERNANDES, 2014)

Foi esse modelo holístico que a CR/1988 consagrou, a Lei Federal n. 11.977/2009 abraçou e a Lei Federal n. 13.465/2917 estaria sendo acusada de rechaçar. É o que se investigará.

\section{Juridicamente: (Últimos) Marcos Regulatórios Federais/Nacionais}

\section{Principiologia Constitucional e Instrumentos Jurídicos de Regularização Fundiária com Assento Constitucional}

Afora toda a principiologia constitucional pro função social da Cidade e da propriedade urbana com que se deve interpretar matéria de direito urbanístico, a Constituição ela mesma previu dois institutos 
jurídico-urbanísticos de garantia da proteção à função social da posse e da propriedade urbana daqueles que as utilizam como moradia: (i) a usucapião especial urbana de imóveis particulares de até 250 metros quadrados situados em área urbana (artigo 183, caput, da CR), regulamentada pelo Estatuto da Cidade em suas modalidades individual e coletiva (artigos 10 do Estatuto da Cidade) e (ii) a concessão de uso especial para fins de moradia (CUEM) ${ }^{13}$ (artigo 183, § $1^{0}$, da CR) de imóveis que, porque públicos, seriam insuscetíveis de aquisição por usucapião, também de até 250 metros quadrados, pelo mesmo prazo quinquenal, a se completar então até 30/06/2001 ${ }^{14}$, prazo hoje estendido para até $22 / 12 / 2016$, e para fins de moradia, disciplinada pela Medida Provisória $\mathrm{n}^{\mathrm{o}}$ 2200/2001, também nas modalidades individual e coletiva.

Observe-se que, em ambas as hipóteses - usucapião especial e concessão especial de uso para fins de moradia - os requisitos são similares: posse, por cinco anos ou mais, ininterruptamente e sem oposição, de imóvel de até duzentos e cinquenta metros quadrados situado em área urbana, utilizando-se-o para moradia do possuidor ou de sua família, desde que não seja proprietário e/ou concessionário de outro imóvel urbano ou rural, diferenciando-se apenas a natureza do bem: privado, naquele e público, neste, e a data-marco do período aquisitivo no caso da CUEM.

Por sua vez, as modalidades coletivas da usucapião especial urbana e da concessão especial de uso para fins de moradia, concebidas de forma a se amoldarem melhor aos assentamentos precários de ruas por vezes inominadas e de limites móveis, podem ser pleiteadas em áreas superiores ao teto constitucional de duzentos e cinquenta metros quadrados, desde que a fração ideal de cada um - pretenso proprietário ou concessionário, respectivamente - não o sobeje.

\footnotetext{
13 Trata-se, para o direito civil, de direito real imposto sobre a propriedade pública urbana, na forma do artigo 1225, XI, Código Civil, com redação dada pela Lei $\mathrm{n}^{0}$ 11.481/2007; para o direito administrativo imobiliário, de mais uma das formas jurídicas de oneração de bens imóveis públicos; e, para o direito urbanístico, de relevantíssimo instrumento de regularização fundiária, consagrando, aos que preencham seus requisitos legais, lídimo direito subjetivo à outorga administrativa da concessão ou, no caso de resistência, de respectivo suprimento judicial.

${ }^{14}$ A nova lei amplia o prazo-marco de aquisição do direito à CUEM para 22/12/2016, mudança legislativa coincidentemente proposta como resultado de pesquisa coordenada por nós, em nome da UERJ, junto ao Ministério da Justiça, pelo Projeto Pensando o Direito, fora no sentido da garantia do direito a qualquer tempo, com fundamento no princípio da isonomia. A propósito, permite-se a remissão do leitor à integra da pesquisa: BRASIL. Ministério das Cidades. (CORREIA, 2016)
} 
Francisco Loureiro (2006, p. 98), em artigo, ressalta que sempre houve dificuldades, no caso de uma favela, por exemplo,

\begin{abstract}
(...) em descrever o imóvel, amarrá-lo a pontos geodésicos e a prédios vizinhos, estabelecer frente para via pública, marcar com precisão e seguranȩa área ocupada. Por isso, o direito subjetivo ao usucapião se esvaía em dificuldades operacionais de materializar o domínio em determinado espaço geográfico. 0 usucapião coletivo tem a função de permitir a superaçãa desses obstáculos, possibilitando, a um só tempo, a regularização fundiária e a conformação urbanística da gleba."
\end{abstract}

Neste sentido, diante da constitucionalização do direito da cidade e por força da principiologia própria à regularização fundiária, a interpretação da usucapião urbana, da concessão especial de uso para fins de moradia e de outros instrumentos de regularização fundiária não pode se dar sob o cânone civilista, mas publicista, mais especificamente, urbanístico, como garantia do acesso à terra urbana e à permanência de seus moradores, preferencialmente, nos locais consolidados de ocupação.

Também a Lei Maior estabeleceu que o Estatuto da Cidade deveria prever os mecanismos necessários à implantação do Plano Diretor pelos Municípios, de forma que pudessem assegurar aos cidadãos o direito fundamental à cidade, de que o direito à moradia adequada seria uma das expressões mais eloquentes, razão pela qual foram previstos novos institutos hábeis à regularização fundiária, como o direito à superfície e, mais recentemente, com a Lei Federal n. 13.465/2017, como se virá de comentar, o a legitimação fundiária e o direito de laje, entre tantos outros.

\title{
Lei Federal n. 11.977/2009
}

A legislação federal sobre gestão do patrimônio público federal sempre esteve na vanguarda em matéria de regularização fundiária, pelo menos do ponto de vista dos instrumentos normativos, como no caso da vetusta concessão de direito real de uso (usualmente conhecida por sua sigla CDRU). Além disso, outras legislações poderiam ser citadas, bem como outros institutos, como o aforamento de terras da União, que resiste no ordenamento jurídico, a despeito da extinção da enfiteuse para terras particulares pelo novo Código Civil ${ }^{15}$, muito embora este esteja na iminência, pelo menos em tese, de

\footnotetext{
${ }^{15}$ Artigo 2.038, caput e $\S 2^{\circ}$, do Código Civil
} 
se tornar ultrapassado, haja vista a tendência do novo marco legal de facilitar a transferência ou a consolidação da propriedade plena em mãos do ocupante de baixa renda de terras públicas, neste caso, mediante remissão de foro.

O recorte metodológico deste ensaio se limita, todavia, às controvérsias entres os marcos regulatórios federais/nacionais mais recentes acerca da matéria da regularização fundiária urbana: a Lei Federal n. 11.977/2009, famosa como instituidora do Programa Minha Casa, Minha Vida, e a Lei Federal n. 13.465/2017, que revogou expressamente todo o Capítulo III daquela, que exatamente deste tema tratava, sem falar nas alterações pontuais conexas de outras legislações, como da Lei de Registros Públicos, de que, pelo menos por ora, também não se irá tratar.

A Lei Federal n. 11.977/2009, em primeiro lugar, reconhecia o protagonismo do Município na condução dos processos de regularização urbanística e fundiária e, em segundo, positivava o conceito de regularização fundiária plena. Neste mesmo sentido, Ligia Melo (2010, p. 180) pontificava que havia "um municiamento do Poder Público local com ferramentas qualificadas para a implementação de uma política urbana mais justa”, tudo de acordo com o planejamento urbano e sua política habitacional firmados pelo Plano Diretor local, não se podendo conceber a Comuna como um "segurador universal do direito à moradia" (idem, 181).

Estabelecia, também, a distinção entre regularização de interesse social e de interesse específico, fixando requisitos para o estabelecimento da primeira compatíveis com sua natureza garantista, mas, mais importante que tudo, criava mecanismos inovadores no processo de regularização fundiária: o procedimento administrativo da demarcação urbanística e o instituto jurídico da legitimação de posse. Era a primeira legislação a criar a figura da usucapião administrativa, na medida em que, após cinco anos da emissão do título de legitimação de posse pela Administração, de motu proprio, já teria o titulado direito subjetivo à respectiva conversão em propriedade perante o Registro Geral de Imóveis competente, se observados os requisitos do artigo 183 da Lei Maior. 
De acordo com a própria lei, demarcação urbanística seria o procedimento administrativo pelo qual o Poder Público demarcava o imóvel de domínio público ou privado, definindo seus limites, área, localização e confrontantes, com a finalidade de identificar seus ocupantes e qualificar a natureza e o tempo das respectivas posses, ao qual se seguiam registros, notificações de confrontantes e uma série de formalidades que, caso não encontrassem oposições pelo longo caminho da burocracia estatal e cartorária, culminariam com os registros do projeto de parcelamento junto ao Cartório dos Registros Gerais de Imóveis competentes, seguidos de atos individuais de legitimações de posse lavrados no âmbito da própria Administração Pública, também registráveis.

De acordo com a lei, embora objeto de registro, o título de legitimação de posse só seria passível de conversão em propriedade cinco anos depois, nos moldes do artigo 183 da Constituição, exatamente aquele que tratava da usucapião especial urbana; daí seu apelido de usucapião administrativa, porquanto independente da judicialização da matéria.

Houve, inequivocamente, uma preferência pela regularização fundiária de interesse social em detrimento da de interesse específico, numa ação estatal positiva em relação àquele histórico fundiário desfavorável em relação à população de baixa renda de que a Cidade do Rio de Janeiro teria sido exemplar.

\section{Medida Provisória n. 759/2016, Projeto de Conversão em Lei n. 01/2017 e Lei Federal n. $11.977 / 2009$}

A Medida Provisória n. 759/2016 já chegou com a pecha de não preencher os requisitos de urgência e relevância exigidos constitucionalmente, ainda mais em processos que costumam levar décadas para serem concluídos, desde o início das obras atá a entrega do título nas mãos do morador. ${ }^{16}$

Mas não foi só isso. Não obstante ter sido festejada pela aparente simplificação cartorial do processo de regularização fundiária, a legislação suscitou dúvidas sobre trazer um conceito de regularização

\footnotetext{
${ }^{16}$ Foi o caso da Comunidade de Fernão Cardin, primeiro Programa Favela-Bairro da Cidade do Rio de Janeiro, que se virá de analisar mais adiante.
} 
estritamente dominial, voltando-se muito mais para a questão cartorial - e mesmo para a transferência de propriedade pública plena e não de apenas alguns de seus atributos, mesmo para população que não seja de baixa renda - ao invés de se voltar para os demais aspectos de uma regularização fundiária plena. ${ }^{17}$

Essa visão estritamente cartorial seria demonstrada em vários preceitos da nova legislação: desde a possibilidade de titulação independentemente de urbanização, até o estímulo à consolidação da propriedade plena de terras públicas, independentemente de medidas outras que protejam essas titulações do mercado especulativo da terra urbana, numa leitura sempre capitalista de toda e qualquer mercadoria, inclusive a terra urbana. (HARVEY, 2006)

O silêncio eloquente à época acerca das zonas de especial interesse social, se não vedava, pela legislação municipal, essa proteção daqueles que agora, titulados, com base em regras urbanísticas mais flexíveis, poderiam vender seu patrimônio ao mercado, que sempre preferiu a propriedade formal para fazer suas transações do que o modelo informal adotado nos assentamentos precários, por outro poderia ser um indício de que a porta estava (literalmente) aberta à gentrificação: um novo gentium ${ }^{18}$, então, viria a ser proprietário, voltando o recém-titulado a sua velha e inexorável (?) condição de nãoproprietário.

${ }^{17}$ Basta cotejar o conceito de regularização fundiária do artigo 46 da Lei Federal n. 11.977/2009 com o do artigo 9o da Lei Federal n. 13.465/2017: aquele com uma perspectiva plena e este mais centrado no aspecto dominial, da titulação:

Lei Federal n. 11.977/2009

Art. 46. A regularização fundiária consiste no conjunto de medidas jurídicas, urbanísticas, ambientais e sociais que visam à regularização de assentamentos irregulares e à titulação de seus ocupantes, de modo a garantir o direito social à moradia, o pleno desenvolvimento das funções sociais da propriedade urbana e o direito ao meio ambiente ecologicamente equilibrado. Lei Federal n. 12.465/2017

Art. 9o Ficam instituídas no território nacional normas gerais e procedimentos aplicáveis à Regularização Fundiária Urbana (Reurb), a qual abrange medidas jurídicas, urbanísticas, ambientais e sociais destinadas à incorporação dos núcleos urbanos informais ao ordenamento territorial urbano e à titulação de seus ocupantes.

${ }^{18} \mathrm{O}$ verbo inglês to gentrify é derivado de gentry, "nobreza, fidalguia", uma velha palavra oriunda, via francês, do latim gentilis, "da mesma família ou raça". Deriva da expressão inglesa "gentrification”. O termo é derivado do neologismo criado pela socióloga britânica Ruth Glass, em 1963, em um artigo no qual ela tratava das mudanças urbanas em Londres. Ela se referia ao "aburguesamento" do centro da cidade, usando o termo "gentry", com uma certa dose de ironia, na medida em que pode ser traduzido como "bem-nascido", em consequência da ocupação de bairros operários pela classe média e alta londrina. 
A Medida Provisória também muito se assemelhava a uma "lei autorizativa", deixando ao sabor do regulamento (supostamente) federal o preenchimento de lacunas das quais não deveria se demitir o legislador, naquilo que se poderia entender como uma violação ao princípio da separação dos poderes.

Quanto à principiologia, ao invés da funcionalização da terra urbana, tratava de princípios como o da competitividade e da ocupação eficiente do espaço, colocando em segundo plano o direito à cidade e, em primeiro, aparentemente, uma relação econômica de apropriação do espaço, aos moldes da tradicional especulação urbana capitalista, sempre denunciada por Harvey. (2010, 2006)

Por sua vez, aspectos positivos, como o direito de laje, nasciam obsoletos, na medida em que previam concessões de uma só sobrelevação, quando o fenômeno da verticalização já é a nova dura realidade com a qual se convive, neste início do século XXI, nas favelas da cidade do Rio de Janeiro, o que se procurou remediar ao depois, quando a Medida Provisória veio a ser convertida na Lei Federal n. $13.465 / 2017$.

Ao longo da discussão acerca da conversão da Medida Provisória n. 759/2016 na Lei Federal n. 13.465/2017, alguns dos defeitos apontados teriam sido corrigidos, de que o próprio direito de laje seria exemplar, embora outras questões, antes tímidas, tenham se aguçado, como ora a equiparação, ora a diferenciação in mala partem da população de baixa renda entre regularização fundiária de interesse social (simplificada como "reurb-s") e regularização fundiária de interesse específico (a "reurb-e"), como se devessem ser tratados igualmente universos de beneficiários abissalmente diversos: a população economicamente vulnerável, que jamais pode se amoldar aos padrões urbanísticos da cidade formal e a população de média e alta renda, que, em tese, optou pela irregularidade urbanística a despeito de dispor de meios financeiros para provê-la.

Manteve-se intacta, outrossim, a possibilidade da titulação, independentemente da urbanização, premissa que fundamentava o conceito de regularização fundiária plena já aqui aclamado. 


\section{Principais Aspectos Controvertidos entre a Lei Federal n. 11.977/2009 e a Lei Federal n. $13.465 / 2017$}

De uma forma simplificadora, pode-se dizer que as principais controvérsias entre os diplomas legais podem ser assim sintetizadas: (i) o conceito de regularização fundiária plena: dominial, urbanística, ambiental e social, precedida de urbanização, naquela e estritamente dominial nesta; (ii) a preponderância dos princípios da funcionalização da propriedade urbana e da cidade naquela e a relevância da "eficiência" na ocupação do solo, nesta (lá, portanto, uma principiologia própria ao Direito Urbanístico; aqui, à Economia); (iii) a criação da figura da legitimação de posse em assentamentos populares consolidados lá, para as quais o proprietário não oferecesse resistência, e, aqui, o reforço à matriz dominial da regularização através da figura da legitimação fundiária tanto de terras públicas, quanto de terras privadas, neste caso, de duvidosa constitucionalidade - mesmo em núcleos urbanos informais caracterizados por condomínios: cidades privadas dentro da cidade de todos ${ }^{19}$; (iv) a distinção parcimoniosa, porém, clara, entre regularização fundiária de interesse social (agora apelidada de "reurb-s") e regularização fundiária de interesse específico (intitulada "reurb-e"), enquanto que em aparente equiparação "perniciosa" entre figuras que buscam objetivos comuns - a regularização -, porém para beneficiários absolutamente díspares; (v) a criação, naquela, da figura da demarcação urbanística e da legitimação de posse, que, aqui, pouco avança em relação às terras públicas do ponto de vista intertemporal, enquanto nesta nova legislação se traz a figura do direito de laje, incluindo-o no rol dos direitos reais e da legitimação fundiária, cuja natureza jurídica parece ser a da propriedade, uma vez que não houve novo acréscimo, no Código Civil, ao rol dos direitos reais, como no caso daquele; (vi) em matéria de isenções, aquilo que dava com uma mão, tira com a outra, na medida em que as isenções cartorárias deverão ser doravante ressarcidas pelos Fundos de Habitação de Interesse Social, justamente aqueles cujos recursos são utilizados em programas de regularização urbanística e fundiária de interesse social; (g) quanto ao procedimento, de fato, desburocratiza a tramitação cartorária, através do ato único de registro - do projeto de aprovação de loteamento e da titulação das unidades autônomas que ele cria, independentemente mesmo da documentação completa

\footnotetext{
${ }^{19}$ Instituto que merece estudo à parte diz respeito aos condomínios de lotes que em tese implicam "rota de fuga" aos ônus urbanísticos impostos pela Lei Federal n. 6.766/1979, permitindo em tese a privatização de espaço público (sem metragem mínima), numa possível volta ao modelo feudal de organização do espaço.
} 
de seus beneficiários (?!), aspecto in fine este bastante temerário, na medida em que sujeito a fraudes que devem ser evitadas pelas Municipalidades -, o que não impede, todavia, a expedição de títulos (atos) administrativos individualizados, mas, por outro lado, transfere para a Administração o ônus da elaboração dos atos de notificação para fins de titulação, o que tende, em tese, a alongar um processo que se pretendia simplificar; mas, (h), por outro lado, parece tornar complexa uma titulação por fração ideal que agora exigiria a instituição de condomínios simplificados urbanos por lote, multiplicando por três ou mais vezes um trabalho que já levava anos para ser concluído.

Por fim, criam-se prazos surreais para problemas históricos, como se em 180 dias a Administração Pública Brasileira fosse resolver as irregularidades urbanísticas brasileiras, de 1500 (ou, mais precisamente, 1530) a 22/12/2016, data-marco (ROLNIK, 2015) escolhida pela lei para que as irregularidades pretéritas sejam sanadas, tentando evitar que doravante prevaleça a cultura da regularização ex post e não a da regularidade ex ante.

\section{Pacto Federativo e Autonomia Municipal}

Para os mecanismos e atributos possivelmente negativos da lei, seria dispiciendo, porém, o discurso da desesperança em relação ao tema da regularização fundiária de interesse social, mas a construção de um modelo que apenas se beneficie de seus pontos positivos.

Com efeito, o novo marco regulatório da matéria constitui-se de normas federais/nacionais veiculadoras de normas gerais que não impedem o exercício da autonomia municipal para a disciplina do direito urbanístico; antes reforçam, a todo momento, por vezes até declinando do exercício da disciplina da matéria por norma geral, o protagonismo do Município na condução do processo de regularização urbanística e fundiária urbana, o que não poderia ser diferente, à luz do texto constitucional.

Não impedem, portanto, a competência do Município para legislar sobre matérias de interesse local, uso e ocupação do solo, serviços locais, desenvolvimento urbano, fomentos extrafiscais como forma de indução ao desenvolvimento urbano sustentável e assim por diante. 
Neste sentido, num exercício de compatibilização entre a nova legislação e o arcabouço normativo local, é possível: (i) manter intacto o conceito de regularização urbanística e fundiária indissociáveis (ou plena) - e sempre precedidas da urbanização da área em que se pretende intervir; (ii) preservar as Áreas de Especial Interesse Social já criadas por lei, de modo a tentar evitar a gentrificação sem coibir a autonomia de vontade do indivíduo de dispor de seu patrimônio (neste caso, para alguém de baixa renda também); (iii) fazer com que a Reurb-e esteja a capitalizar a Reurb-s ${ }^{20}$, num ciclo virtuoso redistributivo em prol de uma cidade menos desigual; (iv) utilizar os novos instrumentos de regularização urbanística, independentemente da intermediação do legislador local, mas, ao mesmo tempo, (v) se valer da autonomia municipal para preservar procedimentos sedimentados que sejam de sua competência, bem como disciplinar novos, em coerência com aquela principiologia que fundamenta o direito à cidade de que se tratou no início deste artigo.

Neste viés, a medida da aplicabilidade da nova lei federal dependerá do exercício da autonomia municipal, uma vez que é o Município que deve ditar a Política Urbana. Isto posto, todos os procedimentos compatíveis com o capítulo III da lei revogada e não proscritos pela lei nova poderão ser preservados, ainda mais que o Plano Diretor da Cidade do Rio de Janeiro caminha neste sentido.

\section{Regularizações Urbanística e Fundiária Cariocas, Titulações 2017 e Perspectivas Futuras}

O processo de regularização urbanística e fundiária carioca não é novo, muito embora a Secretaria Municipal de Habitação, enquanto Pasta autônoma, tenha sido criada em 1994. Intensificou-se, todavia, com o Programa Favela-Bairro, em que já se tentava colocar em prática a união da cidade informal à formal, transformando favela em bairro/comunidade e integrando-a à malha urbana. Na maioria das vezes, todavia, o processo de regularização urbanística e fundiária não conseguiu ser ultimado até a entrega dos títulos, tampouco se estendeu ao período pós-regularização, em que, a rigor, todas as políticas públicas transversais deveriam ser postas em prática para assegurar que as medidas

\footnotetext{
${ }^{20}$ Essa ideia fora inicialmente concebida para a cobrança pela assistência técnica, a ser prestada no processo de REURB-E, por Carlos Portinho, então Subsecretário de Habitação da Pasta de Urbanismo, Infraestrutura e Habitação da Prefeitura da Cidade do Rio de Janeiro, no início de 2017, quando ainda vigente a MP n. 759/2016.
} 
tomadas favoreçam a população que historicamente lá já residia, evitando que o eventual aumento de seu custo de vida provocasse sua mudança para áreas ainda mais irregulares e degradadas da cidade.

Neste recorte metodológico, todavia, examinam-se apenas os últimos atos desses processos de regularização fundiária plena, muitos deles iniciados há vinte anos atrás: a concessão de títulos de garantia da posse ou de virtual titularidade de domínio pelo Município do Rio de Janeiro ocorridas em 2017 junto a três comunidades: duas localizadas na Zona Norte, Fernão Cardin e SOEICON; e, uma, na Zona Sul, a Rocinha.

Os dados foram extraídos apenas da qualificação dos beneficiários dos títulos concedidos no âmbito da Coordenadoria de Regularização Urbanística e Fundiária da Subsecretaria de Habitação da Secretaria Municipal de Urbanismo, Infraestrutura e Habitação da Prefeitura da Cidade do Rio de Janeiro ${ }^{21}$.

Em primeiro lugar, há de se considerar que o volume de titulações corresponde a $21 \%$ de todas aquelas ocorridas de 2002 a 2016; em segundo, leva-se em conta cada uma das comunidades em que ela ocorreu e o perfil socioeconômico de seus moradores, não sem antes se demonstrar o profundo gap existente entre o número de domicílios de uma comunidade a ser regularizada, cujas matrículas individualizadas têm um procedimento prévio meticuloso para serem abertas (os Projetos de Aprovação de Loteamento - PALs), e aquelas titulações que conseguem ser ultimadas.

Observe-se, então, que, desde o início das titulações, em 2002, até 2016, foram concedidos 4895 títulos, enquanto em 2017 foram entregues 1004, 21\% daquele total, conforme gráfico ilustrativo abaixo:

\footnotetext{
${ }^{21}$ A pedido da autora, a tabulação dos dados extraíveis dos títulos foi realizada pelo Arquiteto Marcelo Fonseca, lotado na Gerência de Regularização Fundiária da Coordenadoria, e pela Mestranda em Direito da Cidade, Carolina Bickel: a classificação das profissões por setores foi ideia do primeiro e a contextualização geográfica e histórica da comunidade completa de Fernão Cardin foi iniciativa da segunda, utilizando-se, neste caso, da Dissertação de Mestrado intitulada "Projeto de urbanização de assentamentos precários no Rio de Janeiro e São Paulo: um instrumento de construção de cidade", elaborada por Viviane Manzione Rubio. A contextualização do case Rocinha advém de pesquisa tanto desta quanto de Cláudia Mendes, incumbida de cuidar deste estudo de caso no curso da pesquisa intitulada Não tinha teto, não tinha nada: porque os instrumentos de regularização fundiária (ainda) não efetivaram o direito à moradia no Brasil, coordenada em 2014 pela autora, dentro do Projeto Pensando o Direito. (CORREIA, 2016)
} 


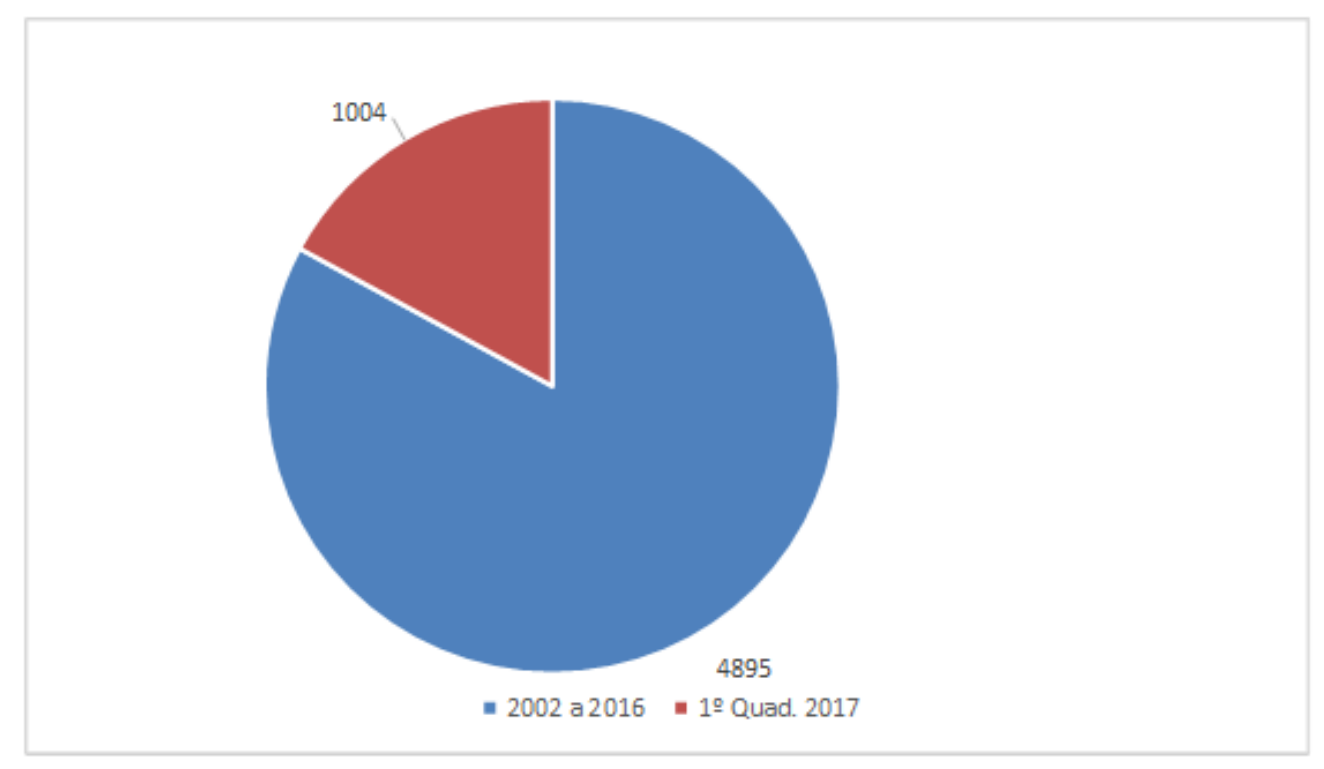

Gráfico 1. Titulações emitidas em processos de regularização fundiária pela prefeitura cidade do rio de janeiro de 2002 a 2017. Fonte: banco de dados smuhi/subh/cruf - pcrj

Do total de títulos concedidos em 2017, distribuídos entre comunidades da Zona Norte e da Zona Sul, foram contabilizados os seguintes percentuais: $69,17 \%$ para Fernão Cardin, 20,60\% para SOEICON e apenas 10,23\% para o sub-bairro Barcellos, da Rocinha ${ }^{22}$.

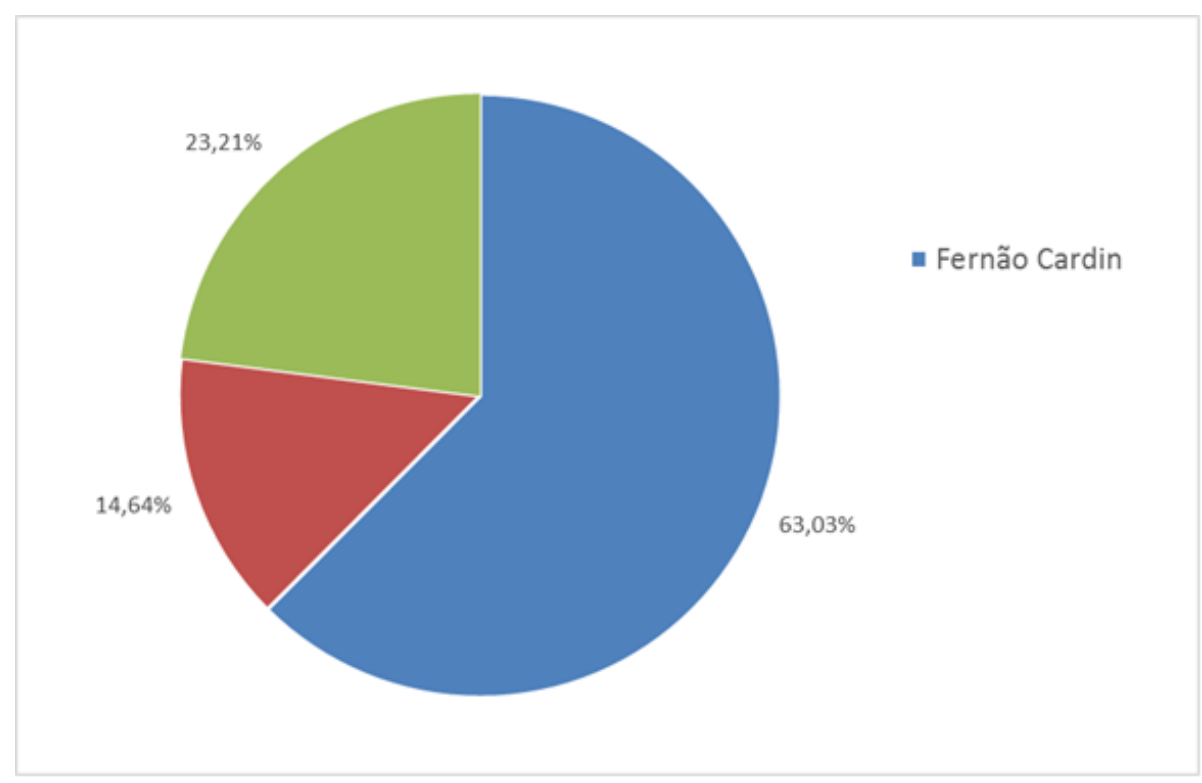

Gráfico 2. Distribuição do percentual de titulações da prefeitura da cidade do rio de janeiro de 2002 a 2017 por comunidade. Fonte: banco de dados smuhi/subh/cruf - pcrj

22 Se levar em conta os títulos de legitimação de posse entregues na Rocinha desde 2014, todavia, esse percentual se modifica. A amostra da vertente pesquisa se restringe, todavia, aos títulos de 2017. 
Uma análise sucinta acerca da urbanização de cada comunidade precederá as reflexões acerca dos dados coligidos da qualificação dos beneficiados por instrumentos de regularização urbanística e fundiária.

Nota-se, da tabela abaixo, que nem todos os beneficiários comparecem à solenidade marcada pela Municipalidade, taxa de abstenção esta que por si só mereceria uma pesquisa qualitativa, mas que muitas vezes é mero reflexo da impossibilidade de comparecimento, depois suprida pela ida do indivíduo à sede da Prefeitura.

\begin{tabular}{|c|c|c|c|c|c|c|}
\hline \multirow[t]{2}{*}{ COMUNIDADES } & \multicolumn{2}{|c|}{$\begin{array}{c}\text { TÍTULOS } \\
\text { RECEBIDOS }\end{array}$} & \multicolumn{2}{|c|}{$\begin{array}{l}\text { TÍTULOS NÃO } \\
\text { RECEBIDOS }\end{array}$} & \multicolumn{2}{|c|}{ TOTAL } \\
\hline & $\mathrm{ABS}$ & REL (\%) & $\mathrm{ABS}$ & REL (\%) & ABS & REL (\%) \\
\hline FERNÃO CARDIN & 507 & $69,17 \%$ & 117 & $43,17 \%$ & 624 & $62,15 \%$ \\
\hline BAIRRO BARCELLOS & 75 & $10,23 \%$ & 72 & $26,57 \%$ & 147 & $14,64 \%$ \\
\hline SOEICOM & 151 & $20,60 \%$ & 82 & $30,26 \%$ & 233 & $23,21 \%$ \\
\hline TOTAL & 733 & $73,01 \%$ & 271 & $26,99 \%$ & 1.004 & $100,00 \%$ \\
\hline
\end{tabular}

Tabela 1. Total dos títulos entregues recebidos e não recebidos em 2017. Fonte: banco de dados muhi/subh/cruf

\section{Fernão Cardin}

\section{Localização e Histórico}

Nota-se, da tabela abaixo, que nem todos os beneficiários comparecem à solenidade marcada pela Municipalidade, taxa de abstenção esta que por si só mereceria uma pesquisa qualitativa, mas que muitas vezes é mero reflexo da impossibilidade de comparecimento, depois suprida pela ida do indivíduo à sede da Prefeitura.

A comunidade está localizada no bairro Engenho de Dentro e próxima a Pilares, a cerca de 14 km do centro do Rio, na Zona Norte da cidade. Insere-se na Área de Planejamento 3 - AP3, subárea 3 - B, na XIII Região Administrativa.

Ocupa uma área de aproximadamente 4,5h, contando com 875 unidades habitacionais e 3.413 habitantes. ${ }^{23}$

${ }^{23}$ Disponível em : <C:/Users/Laps/Downloads/Viviane\%20Manzione\%20Rubio.pdf> Acesso em: 13.07.2017. 


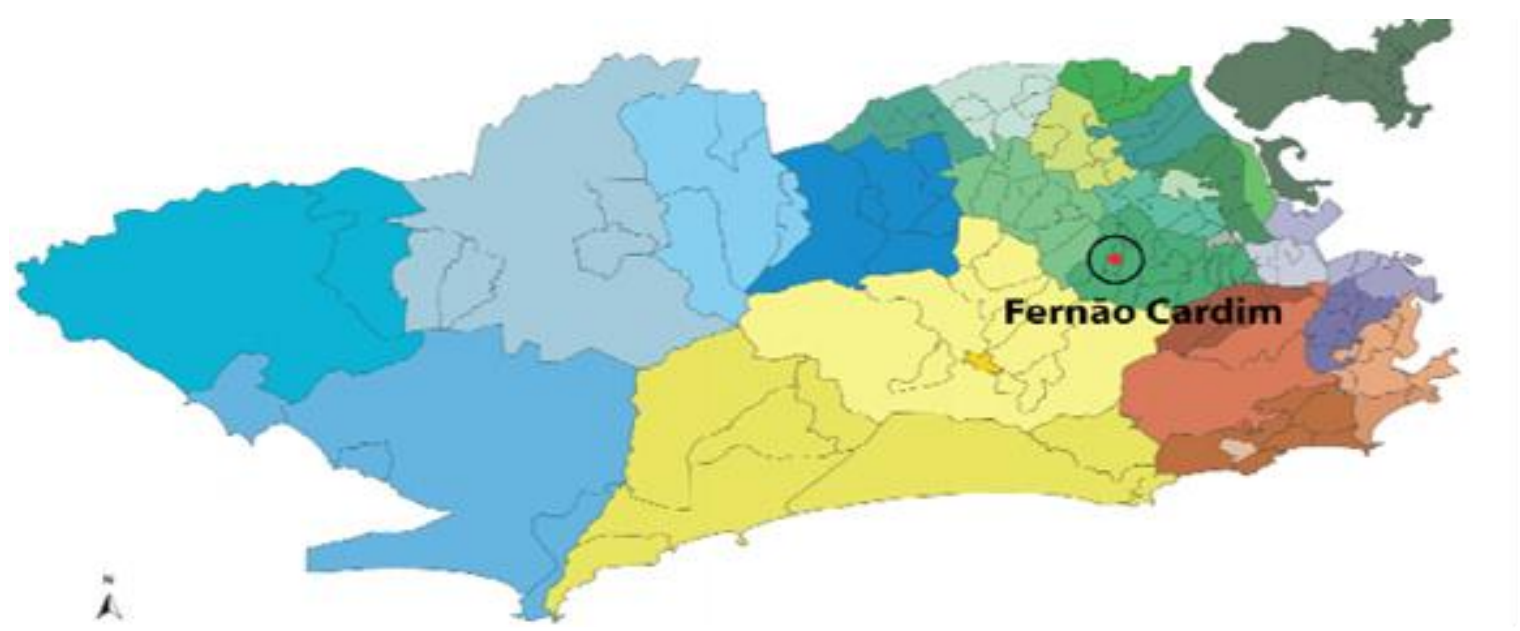

Figura 1. Mapa de localização do conjunto habitacional Fernão Cardin na cidade do Rio de Janeiro.

Fonte: Rubio, Viviane Manzione.

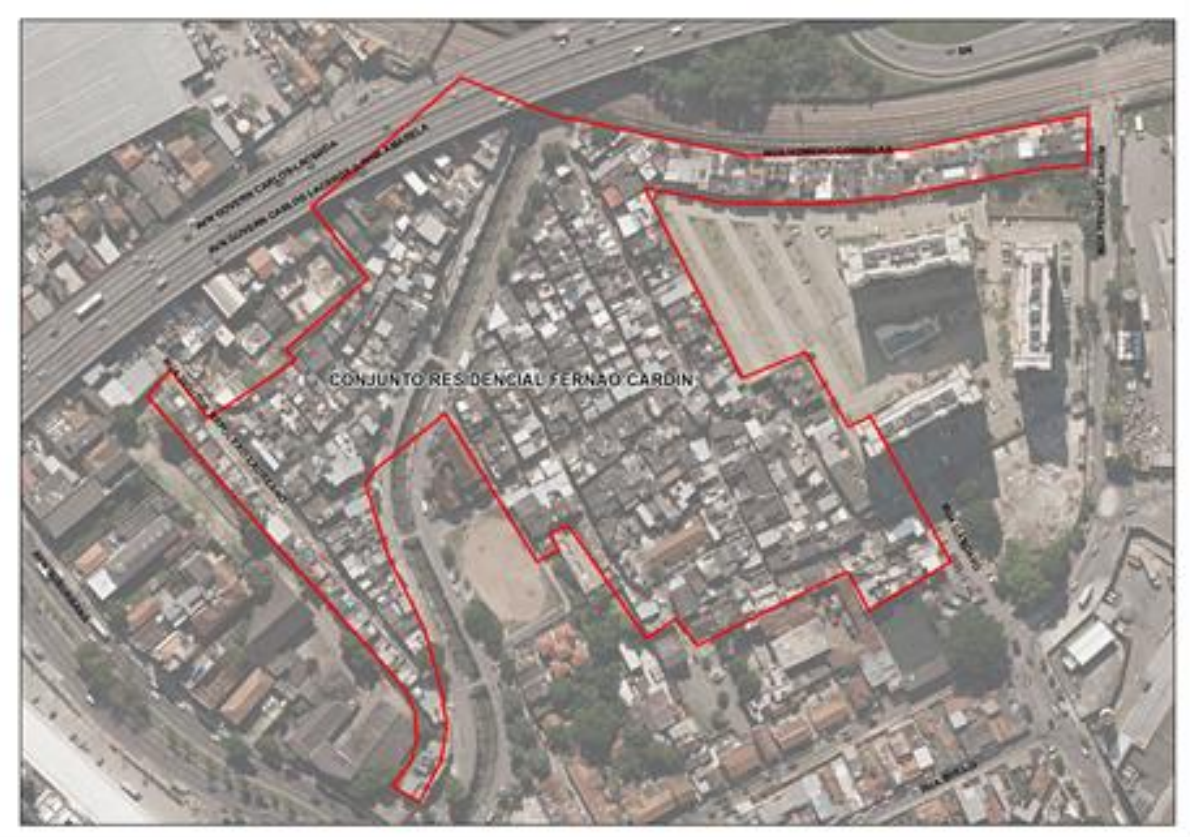

Figura 2. Planta aerofotogramétrica de Fernão Card e seu entorno. Fonte: Sistema de Informações Urbanas

$$
\text { (SIRUB) - Instituto Pereira Passos/RJ }
$$

Oficializado como Conjunto Residencial Fernão Cardim, a comunidade ocupa a região desde 1951. Naquela época, tratava-se de uma região de pastagem onde pequenos animais eram criados. Parte do terreno era alagadiço e seus moradores fizeram um aterro.

Além disso, as desapropriações das favelas de Santa Teresa e Benfica, provocadas pela construção do viaduto Emilio Baungart, impulsionaram a ocupação do local. 
Em 1996 a comunidade recebeu intervenções do Programa Favela-Bairro, que desenvolveu diversas obras, como a canalização de rio, ampliação da acessibilidade, instauração de rede de coleta de esgoto, construção de creches, habitações, comércios etc.

O programa foi responsável ainda pela implantação de um Posto de Orientação Social e Urbanística POUSO, atualmente localizado à Rua do Rio 29, Pilares, inaugurado em 12 de junho de 1997 .

A importância do projeto deve-se em especial à participação popular em todas as etapas do projeto através de consultas à Associação de Moradores e diálogos a partir de solicitações individuais, além de pesquisas sobre o índice de satisfação dos moradores em atenção às intervenções.

A urbanização da comunidade Fernão Cardim culminou na atual titulação de centenas de moradores, embora o programa tenha sido extinto há anos. A Lei Municipal n. 2499/1996 declarou a área da Favela Fernão Cardin como Área de Interesse Social - AEIS. O Decreto Municipal n. 18.407/2000 regulamentou a declaração de AEIS e estabeleceu as normas de uso e ocupação do solo, enquanto o Decreto Municipal n. 17.525 reconheceu a área como parte integrante do bairro do Engenho de Dentro, integrando a comunidade à cidade.

\section{Títulos emitidos versus títulos entregues}

É de 624 o número de titulares cadastrados cujos títulos foram emitidos até abril de 2017. Do total, 495 títulos já foram entregues, enquanto 129 aguardam o titular buscá-lo.

\begin{tabular}{ccc}
\hline Total & 624 & $100 \%$ \\
Entregues até abril de 2017 & 495 & $79,07 \%$ \\
Não entregues até abril de 2017 & 129 & $20,92 \%$ \\
\hline
\end{tabular}

Tabela 2. Títulos emitidos em Fernão Cardin até abril de 2017

Fonte: Banco de Dados SMUHI/SUBH/CRUF - PCRJ 
É de 624 o número de titulares cadastrados cujos títulos foram emitidos até abril de 2017. Do total, 495 títulos já foram entregues, enquanto 129 aguardam o titular buscá-lo.

Os títulos foram entregues, a maior parte, no dia 03 de fevereiro, em cerimônia realizada na Praça das Tamarindeiras, quando representantes da Prefeitura entregaram os contratos de concessão de direito real de uso à população local, neste ensaio chamadas de "titulações por concessão de direito real de uso". O percentual de abstenção deve ser objeto de inferências pelo pesquisador, na medida em que revela ou impossibilidade de comparecimento ou desinteresse ou até descontentamento com a política pública adotada, o que somente poderá ser melhor entendido com outras metodologias, como entrevistas. ${ }^{24}$

As análises seguintes se dão com base nos dados coligidos dos 495 títulos entregues a seus beneficiários.

\section{Sexo dos Titulados}

Verificou-se, dentre os títulos entregues, que $312,63,03 \%$, são mulheres tituladas e 183 são homens, cerca de $36,96 \%$ do total.

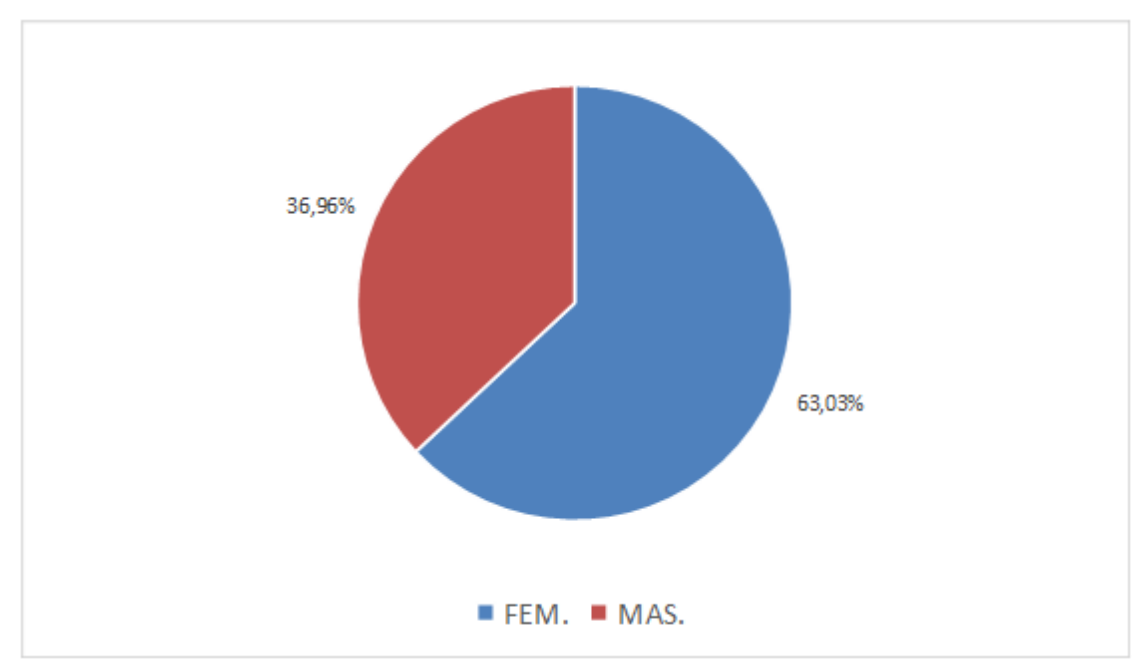

${ }^{24}$ Trata-se de uma segunda fase da pesquisa que se pretende empreender mais adiante, através do Núcleo de Estudos, Pesquisas e Extensão da Linha de Pesquisa de Direito da Cidade da Faculdade de Direito da Universidade do Estado do Rio de Janeiro. 
Gráfico 3. Sexo dos titulados em Fernão Cardin até abril de 2017

Fonte: Banco de Dados SMUHI/SUBH/CRUF - PCRJ

\section{Estado Civil dos Titulados}

Dos 495 titulares cadastrados e cujo título foi entregue até 2017, responsáveis pelas unidades residenciais, verificou-se que a maior parte- 243 - são declarados como solteiros (cerca de $49 \%$ do total), seguido dos casados- 144 (cerca de $29 \%$ do total), divorciados- 47 (cerca de 9\% do total), viúvos- 54 (cerca de 10\% do total), e separados- 07 (cerca de 1\% do total). Em todos os estados civis, as mulheres estão em maior número. No estado civil- viúvo, todas são mulheres.

\begin{tabular}{|c|c|c|c|c|c|c|c|c|c|c|c|c|}
\hline & \multicolumn{2}{|c|}{ CASADOS } & \multicolumn{3}{|c|}{ SOLTEIROS } & DIVORCIADOS & \multicolumn{2}{|c|}{ SEPARADOS } & \multicolumn{2}{|c|}{ VIÚVOS } & \multicolumn{2}{|c|}{ TOTAL } \\
\hline & & & & & & DESQUITADOS & & & & & & \\
\hline \multirow[t]{2}{*}{ OTAL } & $\mathrm{ABS}$ & $\operatorname{REL}(\%)$ & $\mathrm{ABS}$ & $\operatorname{REL}(\%)$ & $\mathrm{ABS}$ & REL $(\%)$ & $\mathrm{ABS}$ & $\operatorname{REL}(\%)$ & $\mathrm{ABS}$ & REL $(\%)$ & $\mathrm{ABS}$ & $\operatorname{REL}(\%)$ \\
\hline & 144 & $29,09 \%$ & 243 & $49,09 \%$ & 47 & $9,49 \%$ & 07 & $1,41 \%$ & 54 & $10,9 \%$ & 495 & $100 \%$ \\
\hline
\end{tabular}

Tabela 3. ESTADO CIVIL DOS TITULADOS EM FERNÃO CARDIN

Fonte: Banco de Dados SMUHI/SUBH/CRUF - PCRJ

O gráfico abaixo desenha os dados da tabela acerca dos "titulados", aqui entendidos como aqueles que foram receber os títulos até abril de 2017:

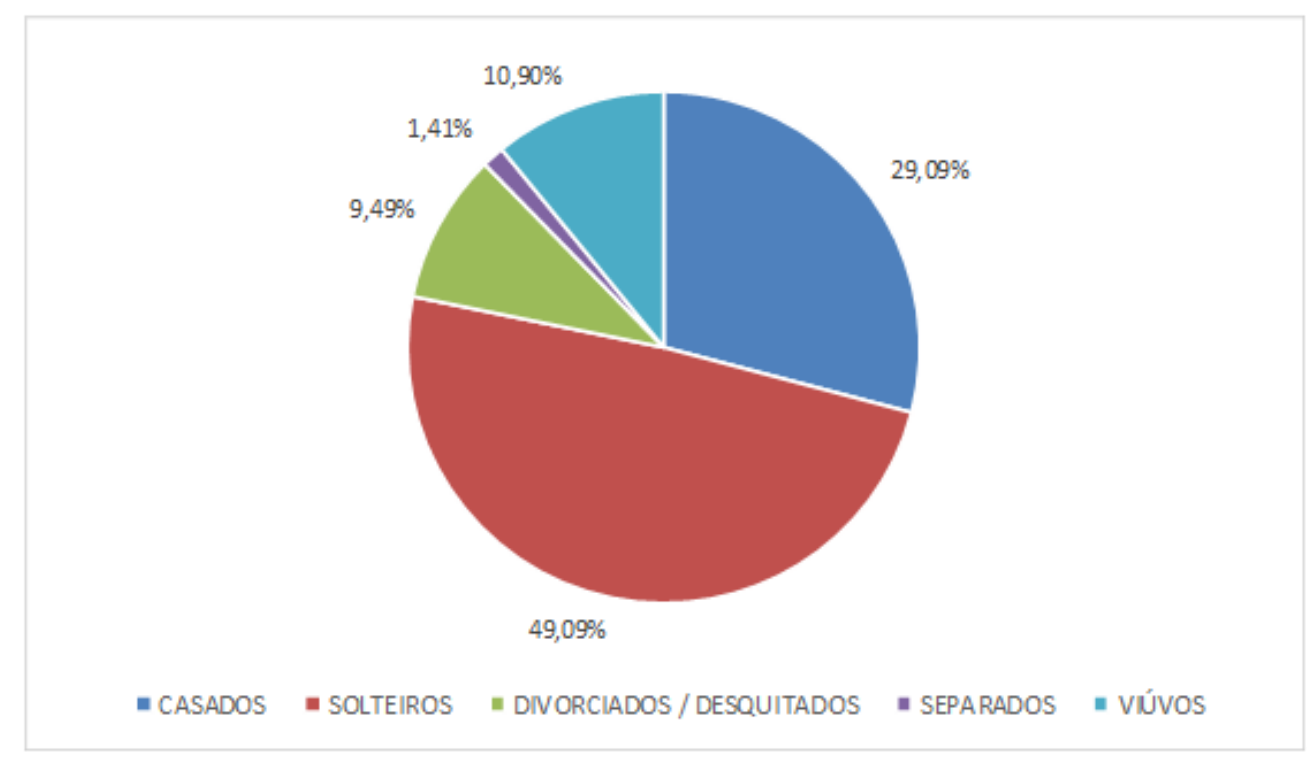

Gráfico 4. ESTADO CIVIL DOS TITULADOS EM FERNÃO CARDIN

Fonte: Banco de Dados SMUHI/SUBH/CRUF - PCRJ 
O número significativo se solteiros, todos com mais de 18(dezoito) anos (já que os dados são extraídos da qualificação daqueles que receberam os "títulos", os contratos de concessão de direito real de uso e que, portanto, detinham capacidade para contratar), pode ser um indício de desvio de finalidade do instituto, que não deve ser o de constituição de patrimônio de duas moradas para uma mesma família, mas de moradia por unidade familiar. Em razão deste dado, solicitou-se que tais contratos fossem objeto de alimentação junto ao CAD-Único, de modo a evitar duplicidade de benefícios.

\section{Regime de Bens dos Titulados}

Entre os titulares cujos títulos foram entregues até abril de 2017 (495 pessoas), verificou-se que a maior parte dos cadastrados, cerca de 84,64,\% não respondeu ou não foi cadastrada a informação no Banco de Dados. Entre os que se dispuseram a prestar a informação, a maioria (13,93\%) declarou-se em regime de comunhão parcial, enquanto apenas cerca de 1,41\% declarou-se em regime de comunhão de bens ${ }^{25}$.

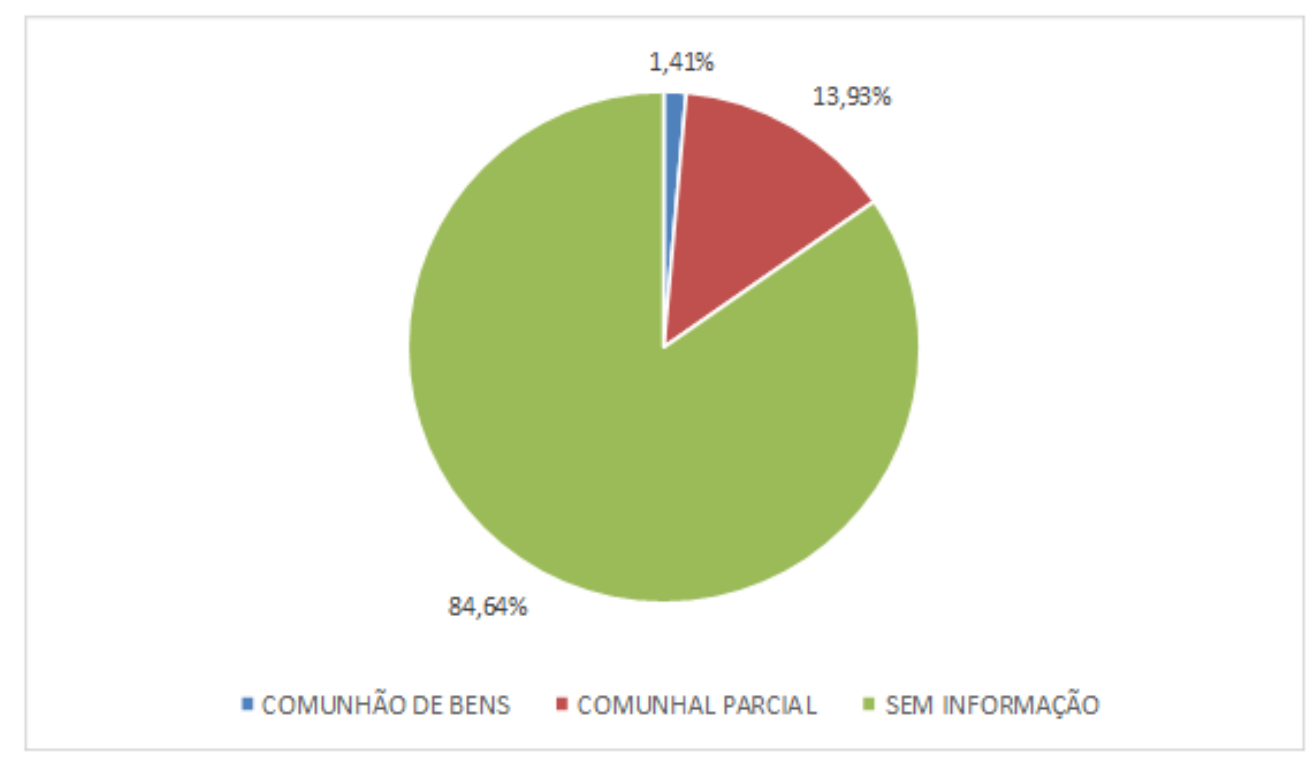

Gráfico 4. REGIME DE BENS DOS TITULADOS EM FERNÃO CARDIN

Fonte: Banco de Dados SMUHI/SUBH/CRUF - PCRJ

${ }^{25}$ Adotou-se o termo empregado no banco de dados da SMUHI/CRUF/GRF. 
A não declaração quanto ao regime de bens é indício de que o habitante de assentamentos precários não detém bens: é o não proprietário de que se tratou no início desta pesquisa, sendo-lhe, portanto, indiferente, o regime de bens que preside seu casamento.

Os dados relativos à profissão serão analisados de forma comparativa entre as três comunidades mais adiante, uma vez que apresentam percentuais parecidos, com forte concentração no setor de prestação de serviços.

\section{Rocinha}

\section{Localização e Histórico}

A Rocinha ocupa uma extensa área ao longo das vertentes dos morros Dois Irmãos e Laboriaux, localizada na região sul do município entre os bairros da Gávea e São Conrado. Está localizada na Área de Planejamento 2 do Município do Rio de Janeiro, formada por 25 bairros, distribuídos por 6 Regiões Administrativas. Está mais especificamente na AP 2.1, região composta por apenas quatro Regiões Administrativas: Botafogo, Copacabana, Lagoa e Rocinha.

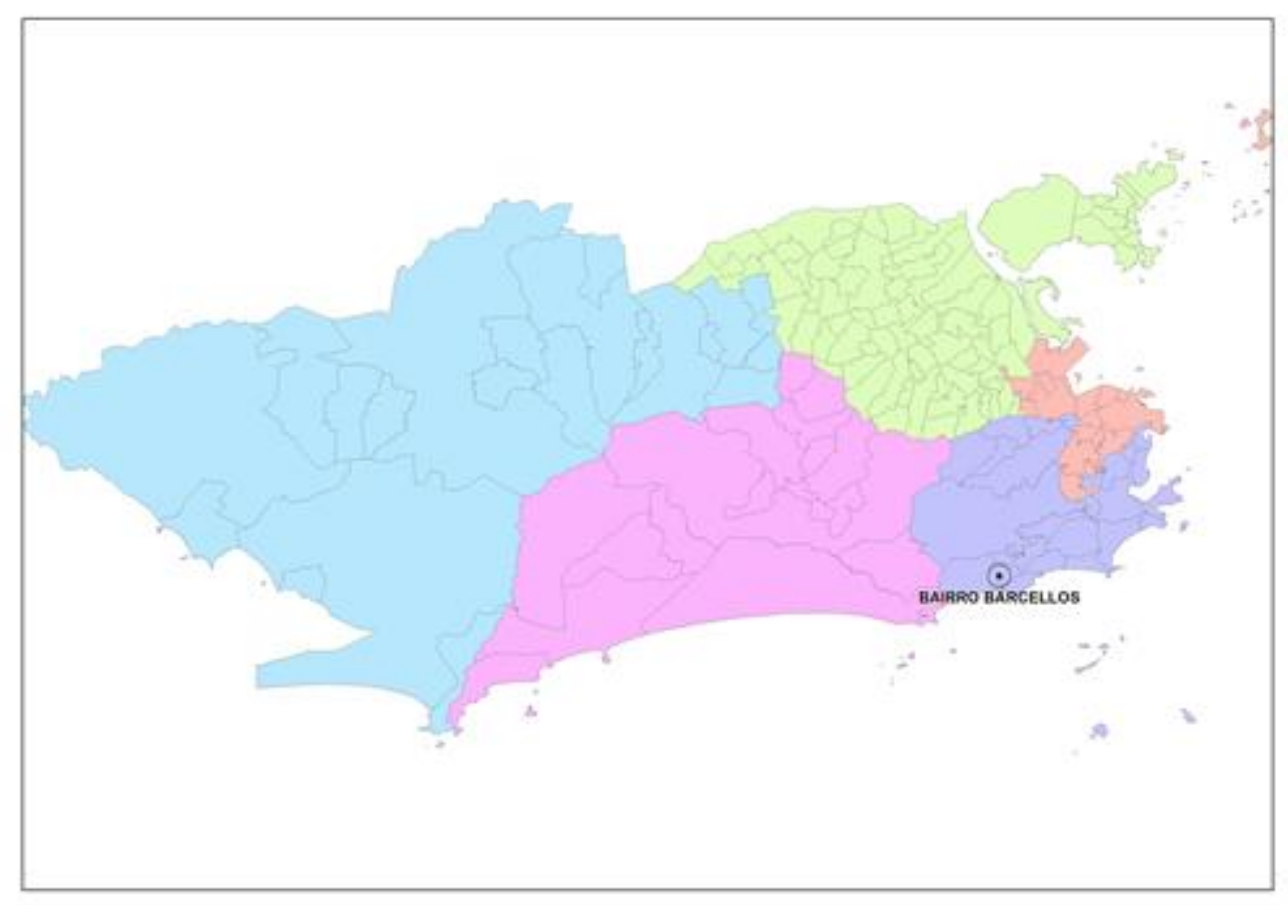

Figura 3. MAPA DE LOCALIZAÇÃO DA ROCINHA NA CIDADE DO RIO DE JANEIRO. 
Sua formação e ocupação remonta ao primeiro terço do século XX. Até 1927 a área ainda era uma grande fazenda. Em 1935, o único acesso, a atual Estrada da Gávea, teve o sistema de iluminação implantada. Com a aquisição pela Cia GUIDON de parte da área em 1937, oitenta lotes sem infraestrutura foram vendidos. Os primeiros moradores foram comerciantes portugueses e operários. Em 1938, com a Estrada da Gávea asfaltada, acelerou-se a ocupação por pessoas que acreditavam que o local era constituído por terras públicas, ocupando áreas próximas. Em 1960 houve um segundo surto de expansão, modificando as feições do loteamento da parte plana (Bairro Barcelos), remoção de favelas da Zona Sul e construção do túnel Dois Irmãos.

Desde então a Rocinha transfigurou-se na favela mais populosa do país segundo o Censo Demográfico 2010 do Instituto Brasileiro de Geografia e Estatística - IBGE, com 69.161 habitantes distribuídos em 25.352 domicílios, dados que expressam vertiginoso crescimento:

\begin{tabular}{ccc}
\hline ANO & POPULAÇ̃̃o & DOMICÍLIOS \\
2000 & 56338 & 16999 \\
2010 & 69156 & 23347 \\
\hline
\end{tabular}

Figura 3. QUANTITATIVO DE POPULAÇÃO E DOMICÍLIOS NA ROCINHA NOS CENSOS 2000 E 2010 Fonte: IBGE Censo Demográfico 2010 / SABREN

Outro fator importante diz respeito a enorme área ocupada pela favela numa das regiões mais valorizadas da Cidade. Somente no período de 1991 a 2000 a Rocinha conheceu o expressivo crescimento de $31,3 \%$, tendência que caracterizou ainda os anos seguintes.

Quanto à legislação, depois de ser elevada à categoria de bairro pela Lei Municipal de 1995, veio a ser declarada Área de Especial Interesse Social pela Lei Municipal n. 3.351/2002. Os Decretos Municipais n. 26.999/2006 e 29.401/2008 cuidaram do reconhecimento dos logradouros e o de n. 28.341/2007, do uso e ocupação do solo, posteriormente alterado. Reconhecem-se 26 subáreas na região: a subárea ou sub-bairro Barcellos fica na parte baixa. Foi esta a área objeto de regularização fundiária, com uma extensão territorial de 53.000.m2, localizada na Estrada da Gávea, lado ímpar, a 226,00 m da Av. Niemayer, em um dos pontos mais valorizados da zona sul da cidade. 


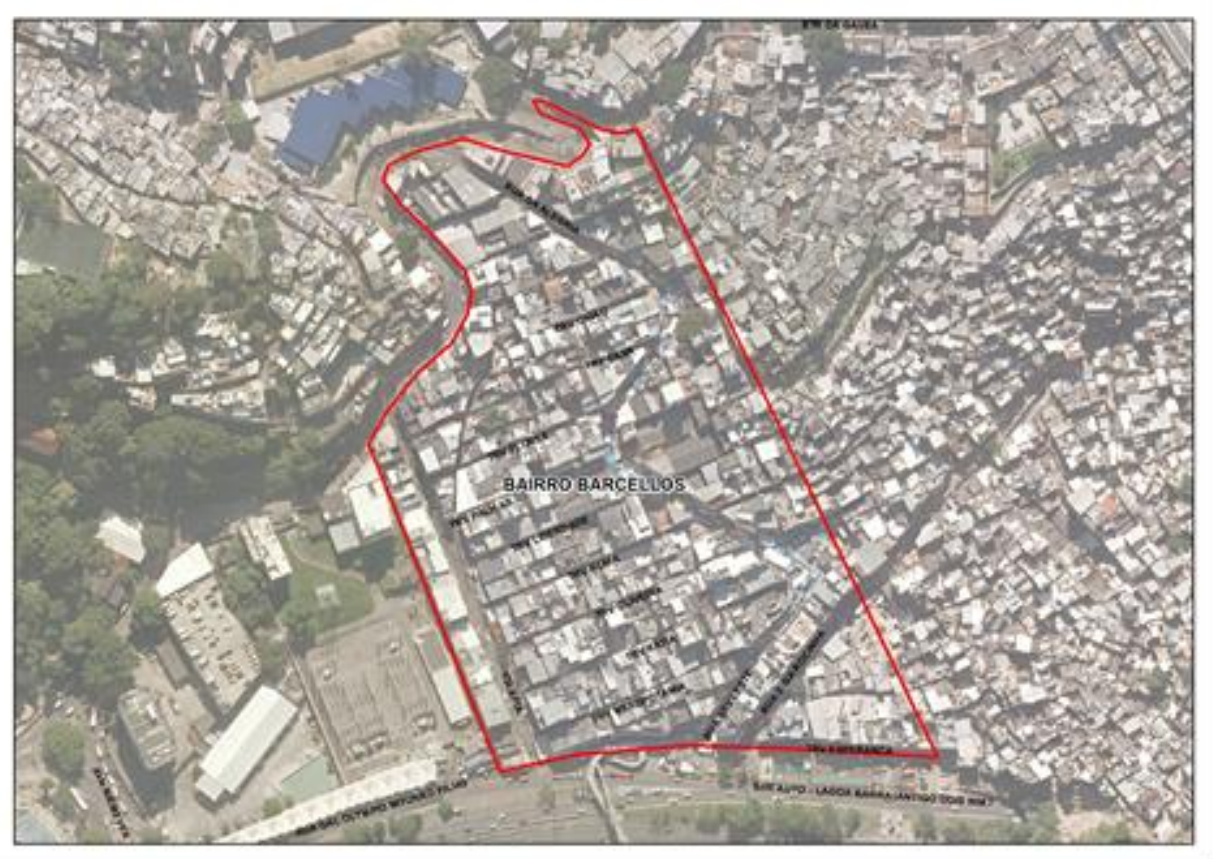

Figura 4. PLANTA AEROFOTOGAMÉTRICA DO SUB-BAIRRO BARCELLOS DA ROCINHA Fonte: Sistema de Informações Urbanas (SIRUB) - Instituto Pereira Passos/RJ

Em cinco de março de 1890, a Companhia de Terrenos Christo Redentor adquiriu o terreno localizado na Estrada da Gávea, lado ímpar, antigos números 3, 5 e 7, uma área de 53.000 m2, conhecido como Bairro Barcellos. Em 1964 a Companhia iniciou a formação de um condomínio com venda de unidades através de promessa de compra e venda em frações ideais, registradas no $2^{0}$ Serviço Registral de Imóveis, na matrícula 97.790.

A Fundação Bento Rubião iniciou o Projeto de Regularização Fundiária no Bairro da Rocinha em 2003, inicialmente em parceria com a Pastoral de Favelas da Arquidiocese do Rio de Janeiro e lideranças comunitárias e, mais tarde, com o apoio do Ministério das Cidades e do Ministério da Justiça e Cidadania e em 2014 com a Secretaria Municipal de Habitação da Prefeitura da Cidade do Rio de Janeiro.

No que concerne ao presente caso, a Fundação Bento Rubião requereu junto à Prefeitura do Rio de Janeiro a aprovação do loteamento do Bairro Barcellos. De fato, a demarcação urbanística do subbairro Barcelos, além de tratada como pioneira (SOARES e GONÇALVES, 2015, p. 251), foi feita num prazo exíguo: "o processo durou aproximadamente um ano desde o início dos trabalhos em 
novembro de 2009 até a averbação do auto em 29 de novembro de 2010.” Todavia, a duração do processo de regularização fundiária como um todo foi bem longo: entre o início do processo, em 2003, e a emissão dos primeiros títulos, em 2014, medearam-se onze anos ...

Dele resultou a concessão de 1.102 títulos de legitimação de posse, registrados em cartório, em dezembro de 2014, e de mais 147, em 2017, que são aquelas objeto do escopo desta amostra inicial (do total das Titulações PCRJ 2017) e sobre as quais se fará a análise sub-amostral em cima dos títulos efetivamente entregues a seus beneficiários até abril de 2017.

Utilizou-se do instrumento de legitimação de posse, seguido do registro de imóveis no RGI, sem a necessidade do penoso e, a princípio, presumidamente longo caminho do processo judicial. De acordo com a lei, por via administrativa, após o decurso do prazo de cinco anos, a aquisição da propriedade por usucapião dependerá de mero registro, não tendo ainda se completado tal período aquisitivo. Por ocasião da entrega dos títulos, vigia o preceito normativo, de natureza legislativa transitória da MP n. 759/2016, que proibia a utilização de novos instrumentos, se já registrado o título de legitimação de posse, como era o caso, razão pela qual sequer se cogitou de sua conversão em título de legitimação fundiária.

Apurou-se que o decurso de tempo entre a averbação da demarcação em si e a efetiva concessão dos títulos de legitimação de posse, que somente ocorreu em 2014, foi de 5(cinco) anos, o que, na ocasião, desmentia o argumento doutrinário de que a desjudicialização evitaria a morosidade dos processos judiciais, cuja média de tempo para institutos "análogos", objeto da pesquisa "Não tinha teto, não tinha nada", já citada, fora praticamente equivalente .

O novo instituto, da legitimação fundiária, que corresponde a uma aquisição da propriedade originariamente, por um lado, afasta essa crítica à legitimação de posse, de que se estaria a dobrar, para quem já detivesse o temo mínimo de aquisição da propriedade por usucapião, o prazo para a segurança do domínio - e não mais da posse -, mas, por outro, gera a insegurança quanto à falta de 
verificação de quaisquer pré-requisitos para a sua concessão, mormente em se tratando de terras particulares.

Para o escopo deste estudo, será analisado o perfil sócio-econômico dos titulados entre os 147 cujos títulos foram emitidos em 2017.

\section{Títulos cadastrados versus títulos entregues}

São em número de 3.957 o total de titulares cadastrados na situação de titulados e em titulação, segundo Banco de Dados da SMUIH/CRUF atualizado até o mês de abril de 2017.

\begin{tabular}{ccc}
\hline & ABS & REL $(\%)$ \\
\hline Titulares Cadastrados & 3.957 & $100 \%$ \\
Cadastrados Cujos Títulos Não Foram Emitidos (em & 2.825 & $71,39 \%$ \\
$\quad$ titulação) \\
Títulos Emitidos
\end{tabular}

Tabela 5. TÍTULOS EMITIDOS NA ROCINHA ATÉ ABRIL DE 2017

Fonte: Banco de Dados SMUHI/SUBH/CRUF - PCRJ

No ano de 2017, que é o de amostra deste ensaio, o total de títulos a distribuir, registrados em cartório, foi de 147, tendo sido recebidos, em solenidade, 72 , sobre os quais se farão as abordagens adiante.

Aqui se repete a mesma impossibilidade ou o mesmo desinteresse para com a política pública da regularização fundiária (aqui apelidada de "titulação") de que se tratou por ocasião da análise do percentual de títulos não entregues em Fernão Cardin.

\section{Sexo dos Titulados}

Verificou-se que, do total de 72 títulos entregues em 2017, 47, cerca de $65 \%$ do total, são mulheres e 25 são homens, cerca de $25 \%$ do total. 


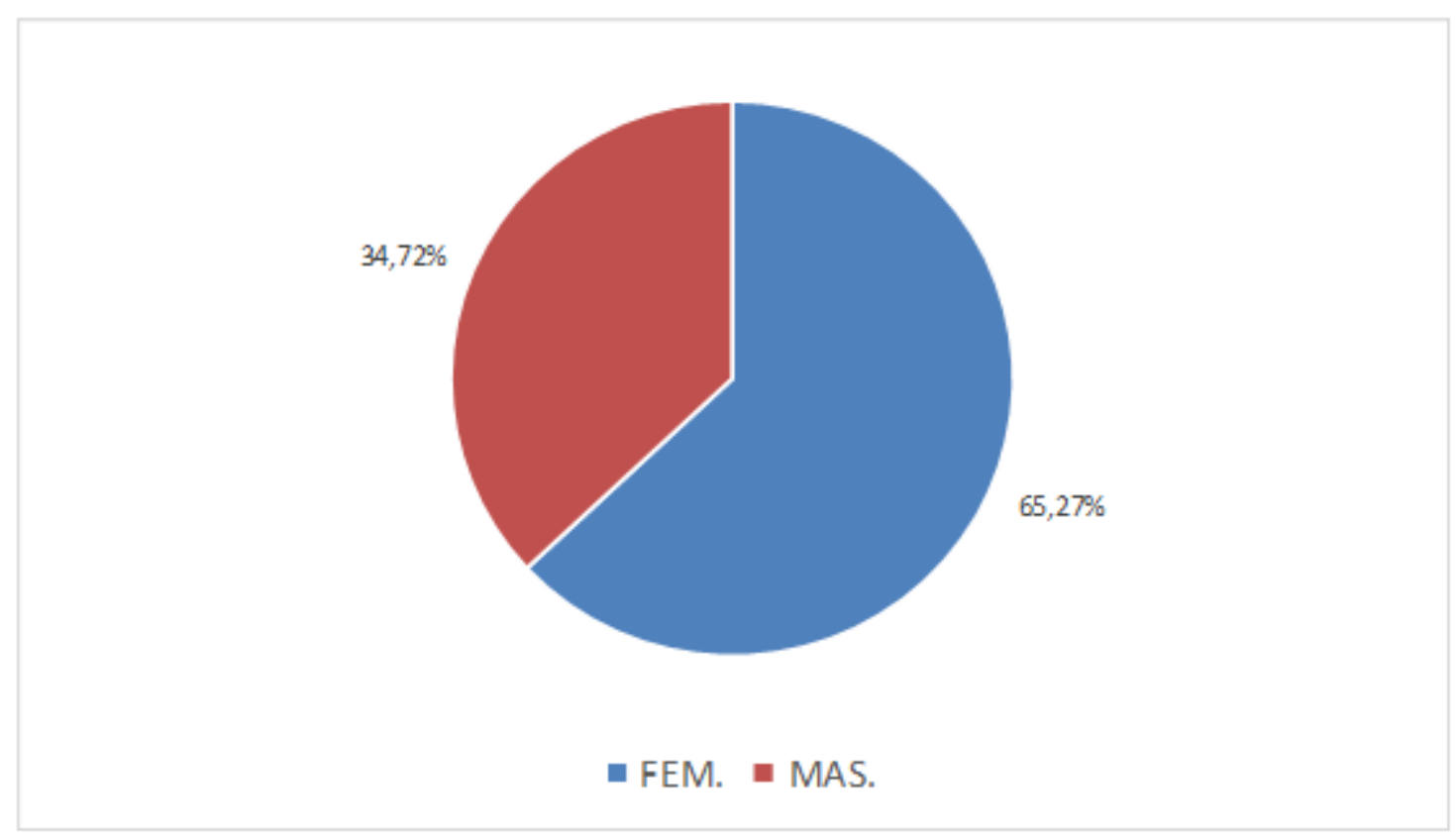

Gráfico 6. SEXO DOS TITULADOS NA ROCINHA EM 2017

Fonte: Banco de Dados SMUHI/SUBH/CRUF - PCRJ

A preponderância das titulações para as mulheres demonstra o empoderamento feminino possibilitado pelas políticas de regularização fundiária adotadas nos últimos anos, graças a alterações normativas decorrentes de pesquisas empíricas em assentamentos populares em geral.

\section{Estado Civil dos Titulados}

Dos 72 titulares cadastrados e titulados responsáveis pelas unidades residenciais, verificou-se que a maior parte- 42 são declarados como solteiros (cerca de 58\% do total), seguido dos casados- 17 (cerca de $23 \%$ do total), viúvos- 08 (cerca de $11 \%$ do total), divorciados- 4 (cerca de $5 \%$ do total) e separados- 01 (cerca de 1\% do total). Em todos os estados civis, as mulheres estão em maior número. No estado civil- viúvo, todas são mulheres. Dois solteiros declararam-se em união estável, um homem e uma mulher. 


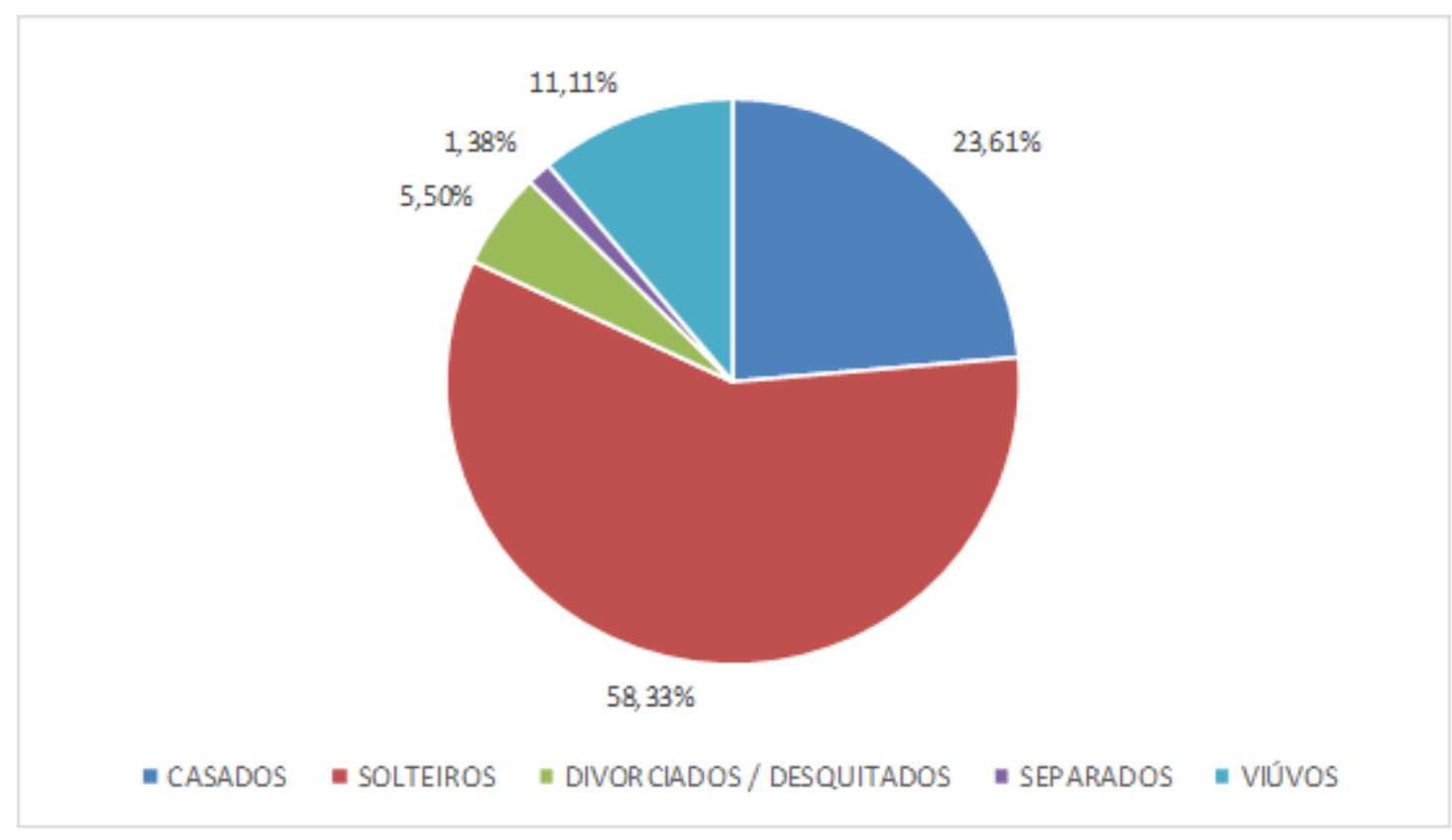

Gráfico 7. ESTADO CIVIL DOS TITULADOS NA ROCINHA EM 2017

Fonte: Banco de Dados SMUHI/SUBH/CRUF - PCRJ

Repete-se aqui a mesma estranheza em relação ao alto percentual de solteiros, tal qual apontado em Fernão Cardin.

Os dados relativos à profissão serão analisados de forma comparativa entre as três comunidades mais adiante, uma vez que apresentam percentuais parecidos, com forte concentração no setor de prestação de serviços.

\section{SOEICON}

\section{Localização e Histórico}

O Empreendimento Habitacional SOEICOM está situado no bairro Marechal Hermes, na XVª Região Administrativa do Município do Rio de Janeiro, na Zona Norte da Cidade do Rio de Janeiro. 


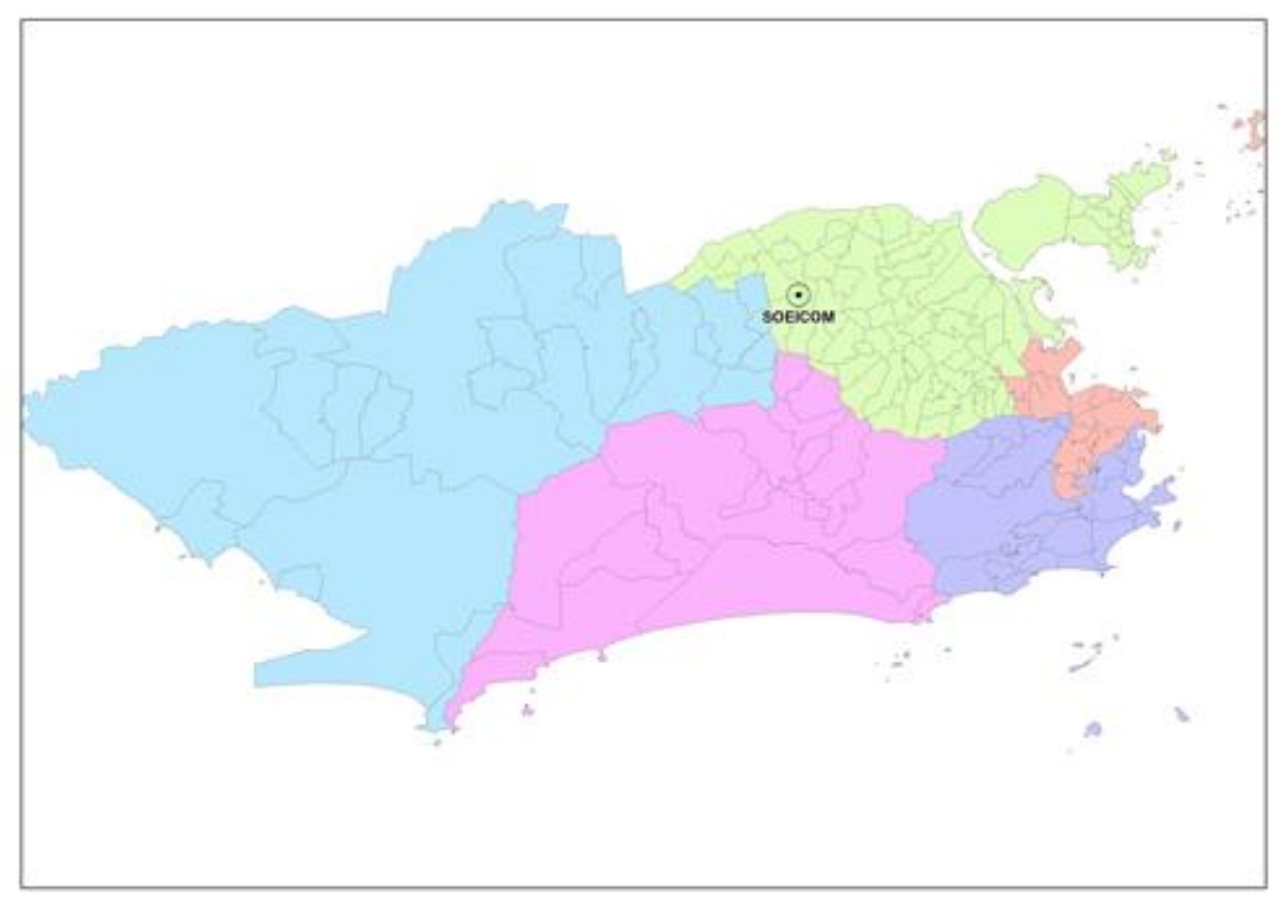

Figura 5. MAPA DE LOCALIZAÇÃO DE SOEICON NA CIDADE DO RIO DE JANEIRO

A área em que hoje está localizado o empreendimento SOEICOM pertencia a uma fábrica de cimento de um grupo português, a Soeicom S/A - Sociedade de Empreendimentos Industriais, Comerciais e Mineração. O Município comprou o terreno e a Caixa Econômica Federal financiou a construção do empreendimento de 264 unidades para o reassentamento de famílias, ocorrido em 2010, bem como a regularização urbanística e fundiária da comunidade, ainda em fase de ultimação.

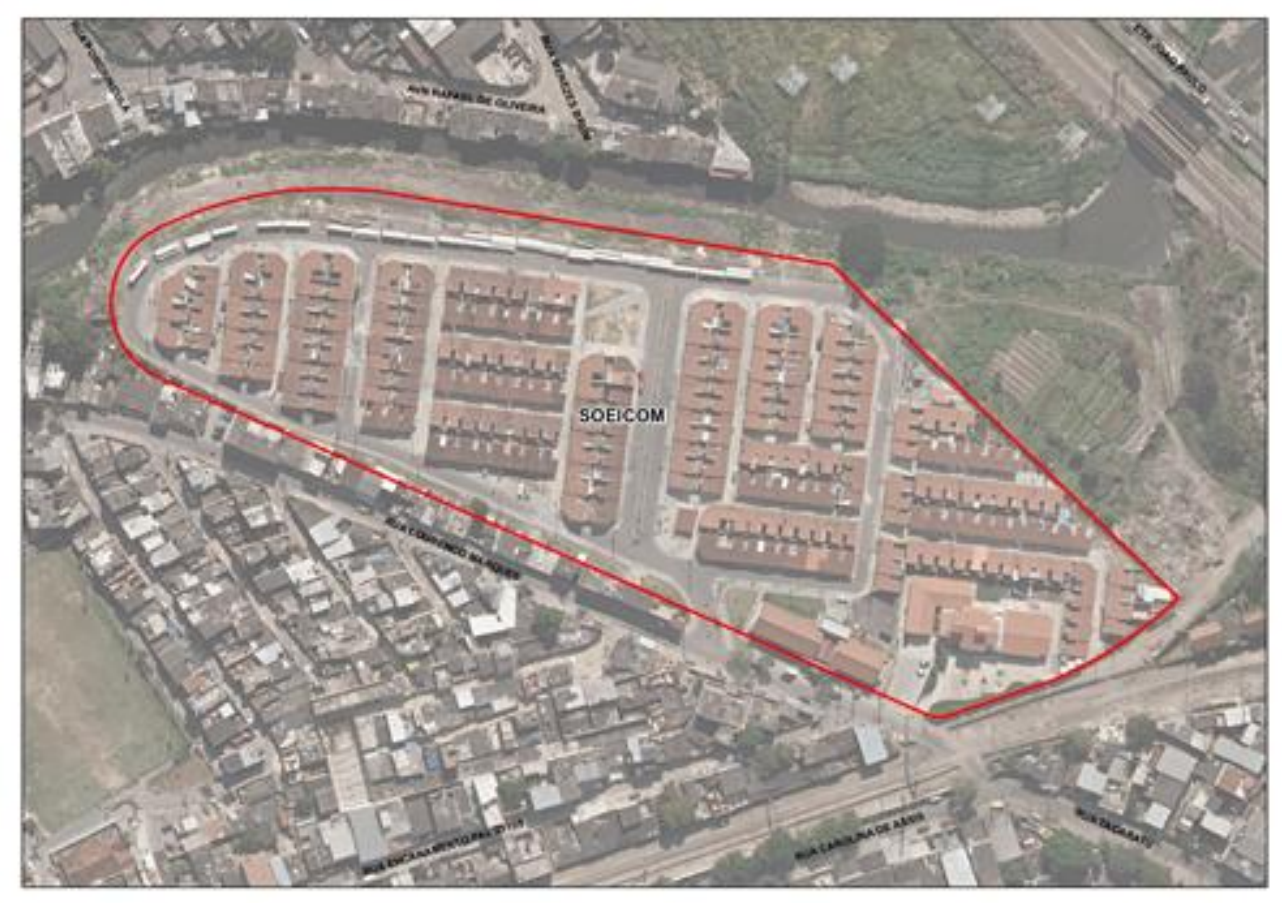

Figura 6. MAPA AEROFOTOGRAMÉTRICO DO CONJUNTO SOEICON PARA REASSENTAMENTO 
Fonte: Sistema de Informações Urbanas (SIRUB) - Instituto Pereira Passos/RJ

A maioria das famílias reassentadas, segundo informação da Coordenadoria de Programas Sociais da Subsecretaria de Habitação da Pasta de Urbanismo, Infraestrutura e Habitação, em entrevista realizada em março de 2017, veio do bairro da Palmeirinha, embora também haja famílias oriundas de outras localidades então cadastradas. Segundo informações colhidas junto à população local, muitas famílias teriam sido expulsas pelo tráfico, por serem oriundas de comunidades dominadas por facções rivais, o que revele ao quanto a segurança jurídica da titulação não pode prescindir da segurança pública do território.

Apesar dos problemas relativos à violência, a então Secretaria Municipal de Habitação, através da então Gerência de Regularização Urbanística e Fundiária deu início aos trabalhos de regularização e: I - elaborou o Projeto de Aprovação de Arruamento e de Parcelamento (PAA e PAL) do Solo; II aprovou o Projeto junto à Secretaria Municipal de Urbanismo, que recebeu a numeração PAA 12.326/PAL 47.923 e III - registrou o Projeto junto ao Cartório do 8ํㅜ́ício de Registro de Imóveis. A Lei Municipal $n^{\circ} 4.730 / 2007$ declarou a área do empreendimento como Área de Interesse Social AEIS e o Decreto Municipal $n^{0} 38.973 / 14$ reconheceu seus logradouros. Não consta para área legislação de uso e ocupação do solo específica.

\section{Número de Cadastrados versus Número de Titulados}

288 é o número total de titulares cadastrados na situação de titulados e em titulação, segundo Banco de Dados da SMUIH/CRUF/GRF, atualizado até o mês de abril de 2017.

\begin{tabular}{lcl}
\hline & ABS & REL(\%) \\
\hline Titulares Cadastrados & 288 & $100 \%$ \\
Cadastrados Cujos Títulos Não Foram Emitidos (em 55 & $21,18 \%$ \\
titulação) & \\
Títulos Emitidos & 233 & $78,81 \%$ \\
\hline
\end{tabular}

Tabela 6. MAPA AEROFOTOGRAMÉTRICO DO CONJUNTO SOEICON PARA REASSENTAMENTO Fonte: Banco de Dados SMUHI/SUBH/CRUF 
Do total, a maior parte foi entregue no dia 17 de maço em cerimônia realizada no Parque Madureira, quando representantes da Prefeitura entregaram os Títulos de Concessão de Direito Real de Uso: assim, foram emitidos inicialmente 168, e, após, mais 35 e, finalmente, mais 30, numa força-tarefa montada pela Gerência de Regularização Fundiária da Coordenadoria de Regularização Urbanística e Fundiária da Subsecretaria de Habitação, perfazendo o total de 233 títulos emitidos dos 288 beneficiários cadastrados.

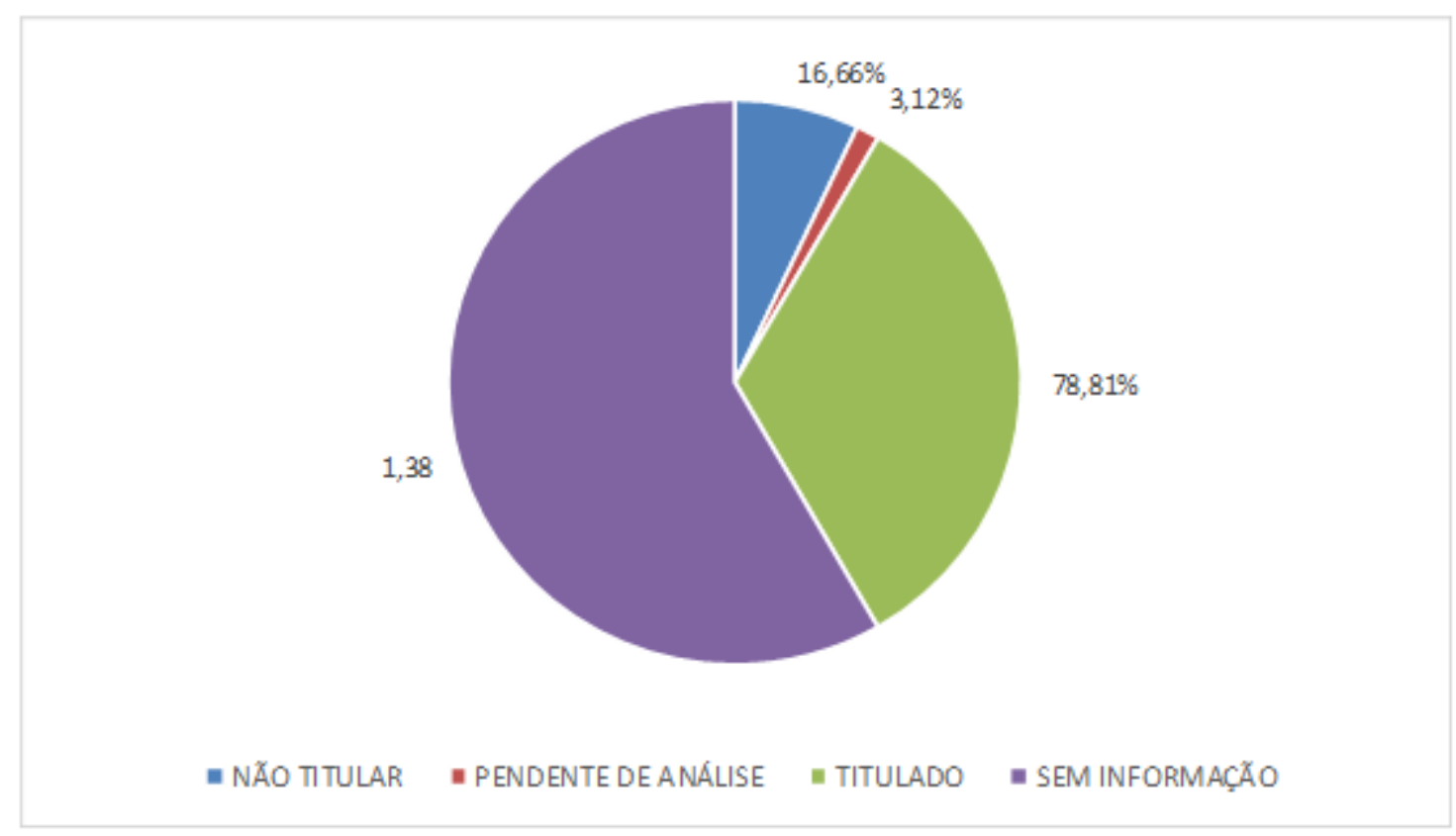

Gráfico 8. SITUAÇÃO DOS CADASTRADOS EM SOEICON EM 2017

Fonte: Banco de Dados SMUHI/SUBH/CRUF - PCRJ

\section{Sexo dos Titulados}

De acordo com as informações coletadas até o momento, foram cadastrados 288 moradores, que culminaram na emissão de 233 títulos (rectius, contratos de concessão de direito real de uso). Verificou-se que, entre os beneficiários de títulos entregues até abril de 2017, 168 ou 71,36\%, são mulheres tituladas e 65 são homens, cerca de $28,63 \%$ do total.

\begin{tabular}{ccc}
\hline SEXO & ABS & REL(\%) \\
\hline FEM. & 168 & $71,36 \%$ \\
MASC. & 65 & $28,63 \%$
\end{tabular}


Tabela \%. SEXO DOS TITULADOS EM SOEICON EM 2017

Fonte: Banco De Dados da SMUHI/CRUF/GRF

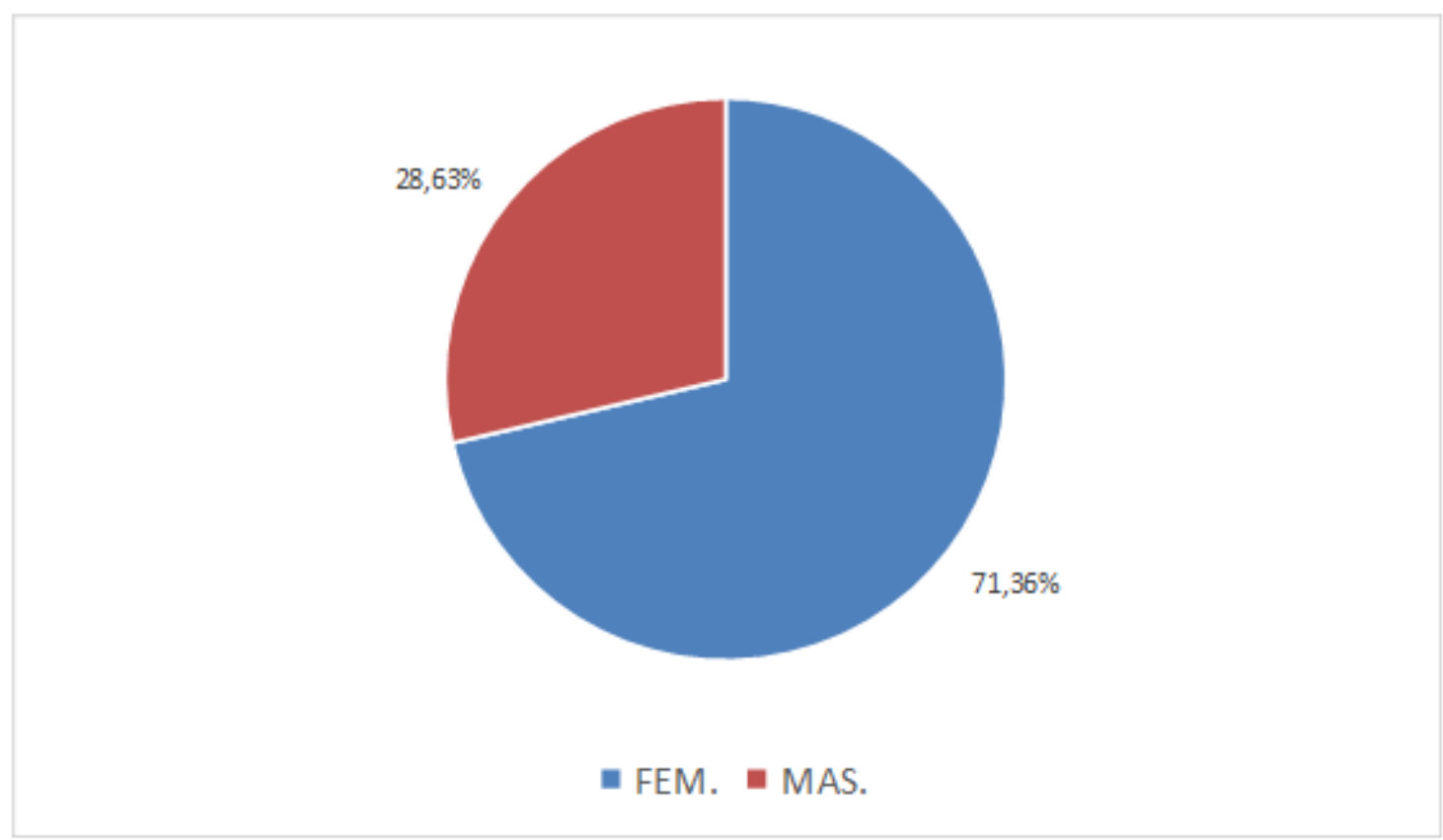

Gráfico 9. SEXO DOS TITULADOS EM SOEICON

Fonte: Banco de Dados SMUHI/SUBH/CRUF

\section{Estado Civil dos Titulados}

Dos titulares cadastrados e cujo título foi entregue até abril de 2017, responsáveis pelas unidades residenciais, verificou-se que a maior parte - 173 - são declarados como solteiros (cerca de 76,21\% do total), seguido dos casados- 30 (cerca de $15,85 \%$ do total), viúvos - 09 (cerca de 3,96\%), divorciados05 (cerca de $2,2 \%$ do total), viúvos- 09 (cerca de 3,96\% do total), e separados- 04 (cerca de 1,76\% do total). Em todos os estados civis, as mulheres estão em maior número. No estado civil 'separadas', todas são mulheres. Ressalta-se ainda que nenhum cadastrado declarou-se "em união estável":

\begin{tabular}{ccccccccccccc}
\hline & \multicolumn{2}{c}{ CASADOS } & \multicolumn{2}{c}{ SOLTEIROS } & DIVORCIADOS & SEPARADAS & \multicolumn{2}{c}{ VIÚVOS } & \multicolumn{2}{c}{ TOTAL } \\
\cline { 2 - 5 } & ABS & REL(\%) & ABS & REL $(\%)$ & ABS & REL $(\%)$ & ABS & REL(\%) & ABS & REL(\%) & ABS & REL(\%) \\
TOTAL & 36 & $15,85 \%$ & 173 & $76,21 \%$ & 05 & $2,2 \%$ & 04 & $1,76 \%$ & 15 & $3,96 \%$ & 233 & $100 \%$ \\
\hline
\end{tabular}

Tabela 8. ESTADO CIVIL DOS TITULADOS EM SOEICON EM ABRIL DE 2017

Fonte: Banco de Dados da SMUIH/CRUF 


\section{Regime de Bens}

Entre os titulares cujos títulos foram entregues em SOEICON em 2017, verifica-se que a maior parte dos cadastrados, $85,9 \%$ não respondeu ou não foi cadastrada a informação no Banco de Dados. Entre os que se dispuseram a prestar a informação, a maioria (cerca de 12,77\%) declarou-se em regime de comunhão parcial, enquanto apenas 03 pessoas declararam-se (cerca de 1,32\%) em regime de comunhão de bens ${ }^{26}$.

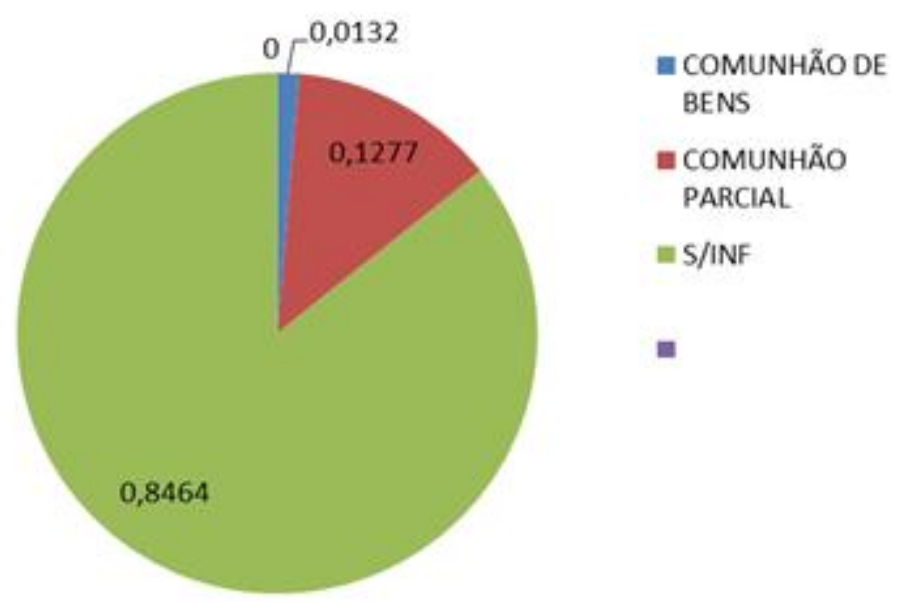

Gráfico 10. ESTADO CIVIL DOS TITULADOS EM SOEICON EM ABRIL DE 2017

Fonte: Banco de Dados da SMUIH/CRUF

Repete-se aqui a mesma estranheza em relação ao alto percentual de beneficiários que sequer prestam a informação quanto ao regime de bens de que dispõem, tal qual apontado em Fernão Cardin. São os mesmos não proprietários de que se tratou no início deste estudo, agora recém-ingressos no rol daqueles que detém algum direito real, ainda que não pleno, pelo menos por ora, sobre bens imóveis.

Os dados relativos à profissão dos titulados, assim como outros aspectos relevantes do muito que se pode extrair de análise com o pouco de dados coligidos, serão interpretados de forma comparativa entre as três comunidades mais adiante, uma vez que apresentam percentuais parecidos, com forte concentração no setor de prestação de serviços.

\section{Quadro Comparativo}

\footnotetext{
${ }^{26}$ Adotou-se o termo empregado pelos beneficiários em suas qualificações/títulos, conforme dados coligidos junto ao banco de dados da SMUHI/CRUF/GRF.
} 
Comparando-se as três comunidades, os itens sexo dos titulados e regime de bens de casamento/união estável em muito permitem que sejam extraídas as mesmas ilações: de prevalência da mulher e de indiferença do regime proprietário para as relações afetivas, pelo menos até então.

Verifica-se também, num quadro comparativo, que a média de ultimação do processo de regularização fundiária por domicílio devidamente individualizado nos devidos projetos aprovados de loteamento, que culmina com a titulação de seus moradores e respectivas famílias, em muito se difere do universo inicial de pretensos beneficiários, o que demonstra que, para muitos dos excluídos - como locatários, titulares de documentação defasada etc -, outras políticas públicas devem ser desenvolvidas. Há um inequívoco afunilamento entre o universo dos pretensamente agraciados e o dos efetivamente aquinhoados ao longo do processo de regularização fundiária.

Varia o grau, todavia, conforme a localização da comunidade e a origem dos beneficiários. Vejamos. De acordo com o levantamento dos títulos emitidos até o ano de 2017, segundo cadastro da SMUIH/SUBH/CRUF - abril de 2017, o maior percentual dos titulados, do universo mapeado, foi na Comunidade de SOEICOM- 233, cerca de 87\% do total, seguido de Fernão Cardin- 624, em torno de 60\% do total. Em Bairro Barcellos há a menor relação entre universo de pretensos beneficiários e efetivos titulados até o ano de 2017 , somente $39 \%$ do total.

Do total dos 5.274 cadastrados para titulação, verificou-se que foram titulados 2.068 , cerca de $39 \%$ do total, e não foram titulados 3.206, cerca de $61 \%$ do total, o que demonstra que outras políticas públicas devem ser adotadas para que esse percentual possa ser incrementado.

Mas não é só isso. Em relação às profissões, agrupadas por setor, há que se fazer também nova comparação entre as comunidades tituladas, conforme gráfico abaixo, sendo que a maioria das profissões declaradas se encontra no setor de prestação de serviços. 


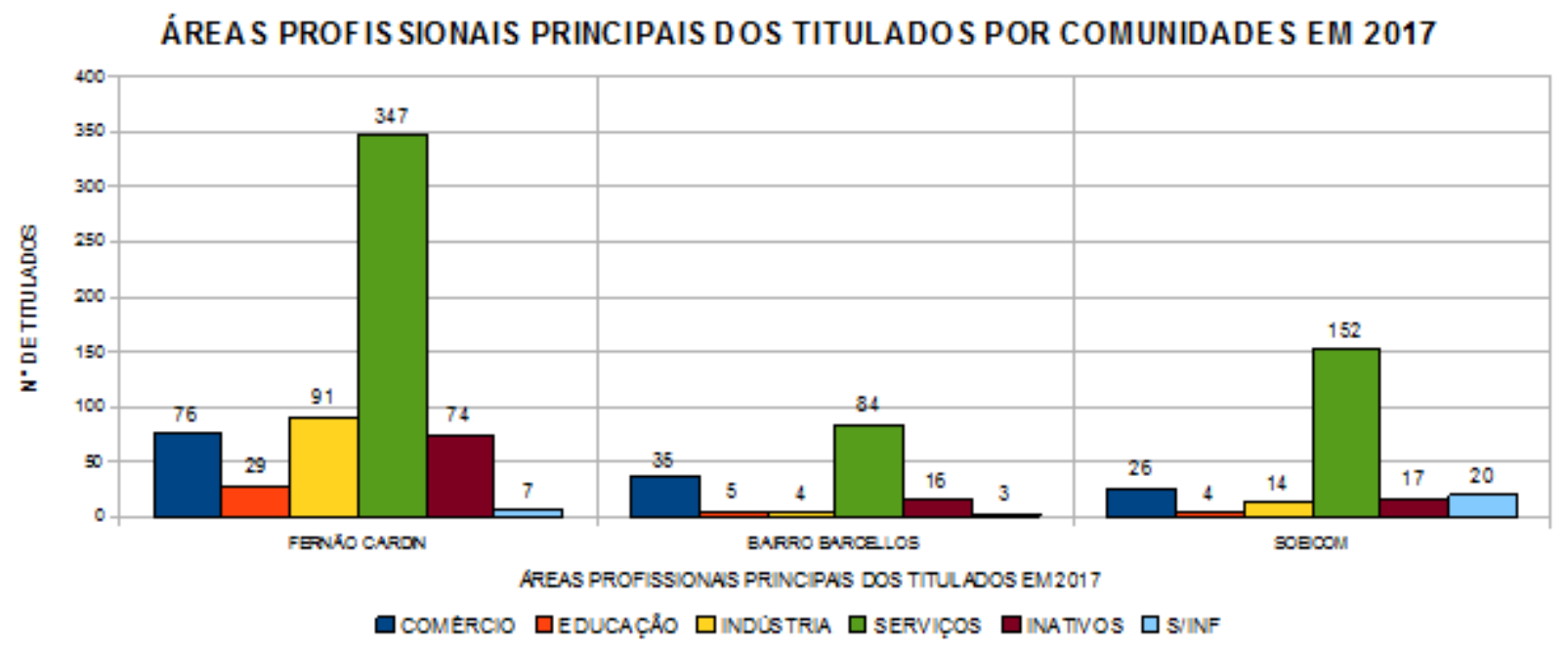

Gráfico 11. COMPARATIVO DAS ATIVIDADES PROFISSIONAIS DOS TITULADOS EM FERNÃO CARDIN, ROCINHA E SOEICON.

Fonte: Banco de Dados da SMUIH/CRUF

Aqui se repete a mesma impossibilidade ou o mesmo desinteresse para com a política pública da regularização fundiária (aqui apelidada de "titulação") de que se tratou por ocasião da análise do percentual de títulos não entregues em Fernão Cardin.

Quanto ao perfil socioeconômico, verifica-se uma certa homogeneidade entre todas as comunidades: (i) empoderamento da mulher; (ii) acesso a bens patrimoniais de que estavam alijados; beneficiários na esmagadora maioria prestadores de serviços para os quais não se exige curso superior, o que demonstra que a legislação de preferência da mulher como titular parece bem-sucedida, que doravante haverá incremento patrimonial desses beneficiários - e conflitos dele decorrentes - e que outras políticas públicas, principalmente as relativas à educação, que permita à população o acesso ao ensino superior, devem ser adotadas pelo Poder Público para que a vida dessas pessoas possa melhorar.

O alto índice de abandono de imóveis para população reassentada por força do tráfico de drogas demonstra que a regularidade fundiária e, de resto, a ação estatal em comunidades socialmente vulneráveis, se mostra muitas vezes refém de um poder extraestatal, que impede a regularização a quem dela deva ser efetivamente beneficiário, indicativo de que à questão da segurança jurídica não se pode dissociar a da segurança pública. 
Deve ser levado em conta, outrossim, a natureza dos títulos concedidos, que demonstra que a multiplicidade permite que se escolha aquele que atenda ao perfil da comunidade e da realidade/titularidade da área cuja regularização fundiária se pretende prover.

As perspectivas futuras levam em conta a titulação do segundo projeto favela-bairro da cidade, em Parque Royal, e a Colônia Juliano Moreira, bem como a potencial utilização de novos instrumentos de titulação, como no caso do aforamento de terras públicas federais, cuja remissão seria agora permitida gratuitamente para a população de baixa renda, nos moldes da nova redação conferida ao artigo 16 -A da Lei Federal n. 9.636/1998, pela Lei Federal n. 13.465/2017²7.

\section{REFLEXÕES FINAIS}

Ainda haverá muitas gerações para que o negro, descendente de escravo, favelado, sem acesso ao ensino superior, com teto, mas sem título, possa se livrar desse ciclo intergeracional de pobreza ou para que ao menos possa viver numa situação menos indigna. Ou se pensam estratégias que evitem a gentrificação ou voltarão a ser não proprietários, não titulados, novos-sem-teto, moradores de rua, adictos ao crack ${ }^{28}$ : aqueles que reviram lixo ou roubam celulares em troca de uma pedra para morrer devagar - ou mais depressa, dependendo do ponto de vista.

Chegou a hora de se dar aos não nada alguma chance.

\section{REFERÊNCIAS}

ABREU, Maurício. A evolução urbana do Rio de Janeiro. Rio de Janeiro: Prefeitura da Cidade do Rio de Janeiro, 1983.

ACOSTA, Claudia. Vivienda digna en Colombia: texto, contexto y debates ante la Corte Constitucional. In: FERNANDES, Edésio e AFONSIN, Betânia. Direito à Moradia Adequada. Belo Horizonte: Forum, 2014.

BALDEZ, Miguel. Ainda a Reforma Urbana: notas sobre algumas conquistas institucionais. Mecanismos de concretização dos Conselhos de participação Popular. Petrópolis: Reproarte Gráfica, 1991.

BARNES, Grenville e GRIFFITH-Charles, Charisse. Assessing the formal land Market and deformalization of property in St. Lucia, ScienceDirect, Land Use Policy 24 (2007), pp. 494-501.

BRASIL. IBGE. Censo Demográfico 2010: aglomerados subnormais: informações territoriais. Brasília: IBGE, 2010

${ }^{27}$ Estudo de caso específico acerca da ultimação do processo de regularização urbanística e fundiária de Parque Royal ficam para a próxima oportunidade.

${ }^{28}$ Pesquisas recentes mostram o incremento da população de rua no Brasil, em especial, de usuários de crack. 
CASTRO, Tânia. Postos de Orientação Urbanística e Social. Rio de Janeiro: Secretaria Municipal de Habitação, 1994.

CORREIA, Arícia Fernandes. Desigualdade até Depois da Morte: ensaio antropológico-jurídico sobre a segregação socioespacial post mortem, Revista do Arquivo Geral da Cidade, Rio de Janeiro, Jan-Mar., 2017.

CORREIA, Arícia Fernandes. COSTA, Emerson Affonso e MOTA, Maurício. Função Socioambiental da Propriedade Privada e Regularização Fundiária Sustentável. Belo Horizonte: Editar, 2016.

. (Coord.) Não tinha teto, não tinha nada: porque os instrumentos de regularização fundiária (ainda) não efetivaram o direito à moradia no Brasil. Brasília: Ministério da Justiça, Secretaria de Assuntos Legislativos, (SAL): IPEA, $2016 . \quad-$ (Série Pensando o Direito; 60)

DINIZ, Mônica. Sesmarias e Posse de Terras: Política Fundiária para assegurar a colonização brasileira. Disponível em: http://www.historica.arquivoestado.sp.gov.br/materias/anteriores/edicao02/materia03/Sesmarias.pdf Acesso em: $31 / 07 / 2017$

FERNANDES, Edésio. Regularização de Assentamentos Informais na América Latina. Disponível em: <http://www.iabrj.org.br/morarcarioca/wpcontent/uploads/2012/12/3-Regularization-of-Informal-Settlements-

Portuguese.pdf $>$ p. 3. Acesso em: 12 Fev. 2014.

HARVEY, David. O enigma do capital e as crises do capitalismo. Tradução de João Alexandre Perchanski. São Paulo: Boitempo, 2010. ᄀ

$\neg$ ᄀ_. A produção capitalista do espaço. São Paulo: Annablume, 2006.

LESSA, Carlos. O Rio de todos os Brasis. 2 edição. Rio de Janeiro, São Paulo, Editora Record, 2001.

LIMA, Ruy Cirne. Pequena Historia Territorial Brasileira. Sesmarias e Terras Devolutas. Brasília: ESAF, 1988.

LEFEBVRE, Henri. Le droit a la ville. Trad. Rubens Frias. São Paulo: Centauro, 2001.

LESSA, Carlos. O Rio de todos os Brasis. 2 edição. Rio de Janeiro, São Paulo, Editora Record, 2001

Loureiro, Francisco. Usucapião coletivo e Habitação Popular. In: Direito à Moradia e Segurança da Posse no Estatuto da Cidade: diretrizes, instrumentos e processos de gestão. Belo Horizonte: Forum, 2006.

MAGALHAES, Alexandre. O Direito das Favelas. Letra Capital: FAPERJ, 1995.

PEREIRA, Júlio César Medeiros da Silva. À flor da terra: o cemitério dos pretos novos no Rio de Janeiro. Rio de Janeiro: Garamond: IPHAN, 2007.

RIBEIRO, Luís Cezar de Queiroz. Governança empreendedorista e Megaeventos esportivos. RIBEIRO, Luís Cezar de Queiroz et al. (Orgs.) Metropolização e Megaeventos: os impactos da Copa do Mundo 2014 e das Olimpíadas 2016. Rio de Janeiro: Observatório das Metrópoles, 2015.2 Disponível em: <http://www.observatoriodasmetropoles.net/images/abook_file/livro_megaeventos_2015.pdf? Acesso em: 30 Nov. 2016.

ROLNIK, Raquel. Guerra dos Lugares. São Paulo: Boitempo, 2015.

SUNDFELD, Carlos Ari. O Estatuto da Cidade e suas diretrizes gerais. In: DALLARI, Adilson Abreu e FERRAZ, Sérgio (Orgs) Estatuto da Cidade (Comentários à Lei Federal n. 10.257/2001. São Paulo: Malheiros, 2002.

VALLADARES, Lícia. Da invenção da favela: do mito de origem à favela.com. Rio de Janeiro: FGV, 2005.

ZALVAR, Alba e ALVITO, Marcos. (Orgs.) Um século de Favela. Rio de Janeiro: FGV, 2006. 